\title{
Sokratik Sorgulama Yöntemine Dayalı Geliştirilen Fen Etkinliklerinin Uygulanabilirliğine Yönelik Öğretmen Görüşleri
}

\section{Teachers' Opinions about the Applicability of Science Activities Developed Based on Socratic Questioning Method}

\author{
İdris AKTAŞ ${ }^{(D)}$, Dr., Amasya Üniversitesi, Eğitim Fakültesi, idrisakasdr@gmail.com
}

Orhan KARAMUSTAFAOĞLU ${ }^{D}$, Prof. Dr., Amasya Üniversitesi, Eğitim Fakültesi, orseka@yahoo.com

\begin{abstract}
Aktaş, í. ve Karamustafaoğlu, O. (2021). Sokratik sorgulama yöntemine dayalı geliştirilen fen etkinliklerinin uygulanabilirliğine yönelik öğretmen görüşleri. Batı Anadolu Eğitim Bilimleri Dergisi, 12(2), 374-405.

Geliş tarihi:24.06.2021

Kabul tarihi:10.08.2021

Yayımlanma tarihi:28.12. 2021
\end{abstract}

Öz. Bu çalışmanın amacı sokratik sorgulama yöntemine dayalı geliştirilen 5, 6, 7 ve 8. sınıf fen etkinliklerinin uygulanabilirliğine yönelik öğretmen görüşlerini ortaya koymaktır. Çalışma deneyimli fen bilimleri öğretmenlerinin sokratik sorgulama yöntemine dayalı geliştirilen fen etkinliklerinin uygulanabilirliğine yönelik görüşlerini ortaya koyarak öğretmenlerin yöntem hakkındaki düşüncelerini belirlemeyi amaçladığından araçsal durum çalışması desenindedir. Bu çalışma 7 (3 kadın, 4 erkek) fen bilimleri öğretmeni ile gerçekleştirilmiştir. Çalışmanın verileri, öğretmenlere yöntemin detayları hakkında bilgi verilip etkinlikleri incelemelerine fırsat verildikten sonra yarı yapılandııılmış görüşmeler ile toplanmıştır. Toplanan veriler içerik analizine tabi tutularak çözümlenmiştir. Öğretmenlerin ifadeleri, yöntemin kavram yanılgılarını ve eksikliklerini gidermede etkili olması ve fen programının sorgulama stratejisine vurgu yapmasından dolayı fen bilimleri derslerinde rahatlıkla uygulanabileceğini, öğrencilerin başarı, kalııılık, motivasyon, aktif katılım, üst düzey düşünme ve iletişim becerisini arttırmada etkili olacağını ortaya koymuştur. Diğer taraftan öğrenci cevapları, öğretmen özellikleri, zaman, sınıf mevcudu gibi etkenlerin güçlüklere neden olabileceği ayrıca basit etkinlik, görseller gibi kavram öğretim araçlarıyla desteklenmesi gerektiğini ortaya koymuştur.

Anahtar Kelimeler: Fen etkinlikleri, Öğretmen görüşleri, Sokrates yöntemi, Sokratik sorgulama.

\begin{abstract}
This study aims to reveal teachers' opinions about the applicability of science activities developed based on Socratic questioning method for 5th, 6th, 7th, and 8th grades. This study is an instrumental case study design because it aims to determine teachers' opinions about the method by revealing the views of experienced science teachers about the applicability of science activities developed based on the Socratic questioning method. This study was carried out with 7 ( 3 females, 4 males) science teachers. The data of the study were collected through semi-structured interviews after teachers were informed about the method and allowed them to examine the activities. The obtained data were analyzed using the content analysis. Teachers stated that the method can be applied easily in science teaching because it is effective to eliminating misconceptions and confusion and emphasizing the inquiry strategy of science programs. Also, they stated it will be effective to increasing students' success, permanence, motivation, active participation, high-level thinking, and communication skills. On the other hand, it has been revealed that factors such as student responses, teacher characteristics, time, and classroom size may cause difficulties and it should be supported with concept teaching tools such as simple activity and visual.
\end{abstract}

Keywords: Science activities, Socrates method, Socratic questioning, Teachers' opinions. 


\section{Extended Abstract}

Introduction. The focus of education in today's societies is to educate individuals who have access to information rather than individuals with knowledge and who produce their own knowledge. Therefore, in recent years, many societies have changed their philosophy of education from teachercentered to student-centered education. Besides various methods are used to make students reach the information, emphasis has been placed on the use of research-inquiry strategy at recently revised curriculum in 2018 in Turkey. One of the research inquiry methods is the Socratic questioning method, which is a special application form of the question-answer method, which is based on the teaching strategy through the discovery.

Socratic questioning method is a method which is based on the adaptation of Socrates' philosophical discussions with students to education and based on the teaching of well-organized questions revealing the information existing in the mind of the individual. The most important feature that distinguishes this method from the question and question-answer technique is that the questions primarily focus on the subject and the concept that the individual has misconceptions, misunderstood or incomplete.

It is seen that the students have difficulty in every level of science education because the science concepts are abstract, the meaning of the concepts used in scientific and daily life is different, and they have lack of prior knowledge and visualization. Students' lack of prior knowledge and misconceptions have negative impact on their science achievement. It is thought that it will be very useful to use the Socratic Questionnaire method in science lessons because it is effective to eliminate misconceptions and learning deficiencies and in relation to concepts. Conducting a study on the applicability of the method based on the activities prepared on the basis of the Socratic inquiry method that can be used easily in science lessons will be important for both raising awareness among teachers and revealing learning outcomes and limitations that they will create in science lessons. For these reasons, this study aims to determine teachers' opinions about using the method based on the activities based on Socratic questioning in science subjects developed for $5^{\text {th }}$, $6^{\text {th }}, 7^{\text {th }}$, and $8^{\text {th }}$ grades.

Method. This study is a case study because it aims to reveal the applicability of the method by determining the opinions of experienced science teachers about the method based on science activities developed based on the Socratic questioning method. This study was carried out with 7 (3 females, 4 males) science teachers working in 6 different secondary schools. Average professional experience years ranging from 7 to 22 of teachers who participated in the study was 14.5. 4 of the teachers work in the city center, 2 of them work in the district center and 1 works in the village secondary school. In addition, 2 of the teachers are continuing their doctorate education and 2 of them are graduate students. The data of the study were collected through semi-structured interviews after teachers were informed about the method and allowed to examine the activities. Semi-structured interview questions are prepared according to five main topics including teachers' knowledge about the Socratic questioning method, whether the method is applicable in science lessons, the effect of students on learning outcomes, the difficulties encountered during the implementation of the method and the opinions of the teachers about the prepared activities. The obtained data were analyzed by two encoders using the content analysis method.

Results. The teachers stated that they had some information about the method, some teachers used the question- answer method and some teachers used the discovery method in their lessons, but they did not use this method and systematic questions. Teachers stated that the method could be applied easily in science classes because it is effective to eliminating misconceptions and confusion and emphasizing the questioning strategy of science programs. The teachers stated that the method 
is partially applicable to such subjects because of the difficulty in teaching subjects that requiring formula, abstract subject, subjects with a high number of concepts, concept definitions. Also, they stated that it would be effective to increasing students' success, permanency, motivation, active participation, high-level thinking, and communication skills when the method used in science subjects. It has been revealed that factors such as student responses, teacher characteristics, time, and classroom size may cause difficulties and that should be supported with concept teaching tools such as simple activity and visual.

Discussion and Conclusion. When the teachers' opinions are taken into consideration, it can be said that the method can be easily applied in the science class because of the properties of the Socratic questioning method and the characteristics of the science course are compatible. However, it has been also concluded that the science course can be applied enriching it with various activities in some subjects which are abstract or teaching concept. Training can be given that the introduction of this method for in-service teacher and faculty members can include this method in their teaching courses to inform the prospective teachers because Socratic questioning method is a viable method in science lessons and the teachers confused this method with the question-answer method. Since teacher's competence will cause difficulties during the implementation of the method, the teachers who will use this method in their courses must determine the well-prepared systematic questions before using the Socratic Questioning Method in their courses and be prepared for the possible answers that may come from the students. Also, researchers can develop Socratic questioning activities for various science subjects and conduct experimental studies examining the effects of these activities on learning outcomes because the Socratic questioning method is a subject that is rarely studied. 


\section{Giriş}

Günümüz toplumlarında eğitimin odağını bilgiye sahip olan bireylerden ziyade bilgiye ulaşma yollarına sahip olan, kendi bilgisini kendisi üreten bireylerin yetiştirilmesi oluşturmaktadır (Milli Eğitim Bakanlığı [MEB], 2013). Bu nedenle son yıllarda ABD, İngiltere başta olmak üzere birçok toplum eğitim felsefesini değiştirerek öğretmen merkezli eğitimden öğrenci merkezli eğitime geçmiştir. Bu bağlamda birçok ülkede olduğu gibi Türkiye'de öğrenme sürecinde öğrenenin aktif olduğu ve kendi bilgisini oluşturduğu yapılandırmacılık modeline geçmiştir. Bu modelle birlikte öğretmen, öğrenci, öğrenme ortamı, öğrenme süreci, öğretim yöntemleri ve değerlendirme teknikleri süreç içerisinde yeniden ele alınarak güncellenmiştir. Ancak öğretimin tüm öğeleri gözden geçirilirken öğrencinin bilgiyi keşfetmesi/yapılandırması ve aktif katılımının sağlanması gerekliliği değişmeyen öğeler olmuştur. Öğrencinin bilgiye ulaşması için çeşitli yöntemler kullanılsa da Türkiye'de en son yenilenen 2018 yılı öğretim programında araştırma sorgulama stratejisinin kullanılması üzerine vurgu yapılmıştır (MEB, 2018). Araştırma sorgulama yöntemlerinden biri de buluş yoluyla öğretim stratejisine dayanan ve soru cevap yönteminin özel bir uygulama biçimi olan sokratik sorgulama (Sokrates yöntemi, buldurma yöntemi) yöntemidir.

Sokratik sorgulama yöntemi Sokrates'in öğrencileriyle gerçekleştirdiği felsefi tartışmaların eğitime uyarlamasıyla ortaya çıkan ve iyi organize edilmiş sorularla bireyin zihninde var olan bilgilerin açığa çıkartılarak öğrenmenin gerçekleşmesini sağlayan bir yöntemdir (Aydın, 2001; Delić ve Bećirović, 2016). Sokrates, diyalog halinde öğrencilerine sorular sorarak bilgiyi buldurmaktaydı. Bu yöntemde önemli olan ve bu yöntemi soru cevap tekniğinden ayıran en önemli özellik, soruların öncelikle bireyin kavram yanılgılarının olduğu, yanlış veya eksik bildiği konu/kavramlar üzerine yoğunlaşmasıdır (Driver, Guesne ve Tibergihen, 1998). Bireye bildiği konu/kavramlarla ilgili çeşitli sorular sorarak yanlıs bilgiye sahip olduğunun veya bilmediğinin fark ettirilmesinden sonra yeni sorularla doğru bilginin öğretilmesidir (Chang, Lin ve Chen, 1998; Knezic, Wubbels, Elbers ve Hajer, 2010). Bunun için öğrencinin sorulan sorulara cevap vererek aktif katılımı sağlaması gerekmektedir. Sokratik sorgulama yöntemi çürütme (alay) ve doğurtma olmak üzere iki temel aşamadan meydana gelir (Aydın, 2001; Delić ve Bećirović, 2016; Zeybek, 2019). Her iki aşamada ikişer basamaktan oluşur. Çürütme aşaması başlama ve bilmediğini hissettirme, doğurtma aşaması ise buldurma ve özetleme basamaklarından oluşur. İki aşama ve her aşamada iki basamak olmak üzere toplam dört basamadan oluşan yöntemin basamakları şöyle açıklanabilir (Knezic vd., 2010; Sönmez, 2005; Zeybek, 2019). Çürütme aşamasının iki basamağından biri olan başlama basamağında, öncelikle öğrencinin daha önce bildiği kavramlarla ilgili sorular sorularak öğrencinin konuya güdülenmesi sağlanır. Daha sonra ikinci basamak olan bilmediğini hissettirme basamağında sorulan sorular veya örnek durumlarla öğrencinin bilgisinin eksik veya yanlış olduğu öğrenciye fark ettirilir. Bu aşamada öğretmen hiçbir şey bilmiyormuş gibi davranarak öğrencilere sorular sorar. Böylece öğrenciler güdülenerek sorgulamaya hazır hale gelir. Bu aşamanın sonunda öğretmen öğrencilerin cevaplarındaki çelişkileri ortaya koyar ve öğrencinin bilgilerinin yanlış veya eksik olduğunun farkına varması sağlanır. Doğurtma aşamasında ise, iyi organize edilmiş yeni sorular ve ipuçlarıyla, öğrencinin düşünme ve sorgulama yeteneği kullanılarak doğru bilgiye ulaşması sağlanır. Öğretmen öğrencinin bilmediği bilgileri sistemli sorularla adım adım buldurmaya çalışır. Bu aşamanın sonunda veya öğretmen ihtiyaç duyduğu yerlerde ulaşılan bilgiyi öğrenciden özetlemesini ister veya kendisi özetler. Bu yöntemi uygulayan öğretmenlerin ihtiyaç duyduğu her basamakta anlam çözümleme tabloları, görseller, örnek olaylar, yapılandırıımış gridler gibi kavram öğretimi araçlarını kullanmaları faydalı olacaktır.

Sokratik sorgulama yönteminde sorular öğrencilerin ön öğrenmelerini ortaya çıkarma veya beyin fırtınası başlatma amaçlı kullanılmalıdır (Knezic vd., 2010). Öğretmen dersin başında öğrencilere kavramların tanımlarını vermez. Önceden hazırlamış olduğu mantıklı bir dizi sistematik soruyu öğrencilere sorarak ön bilgilerinden yeni kavramlara ulaşması için çaba sarf eder (Chang vd., 1998). Öğrenciler, öğretmenin rehberlik etmesiyle sorulan soruları, verilen cevapları ve örnekleri 
düşünüp analiz ederek tanımlara kendisi ulaşır. Bu yöntemde öğretmen ve öğrenci ortak bir çaba harcayarak sonuca giderler. Sokratik sorgulama yönteminin uygulanabilmesi için iki önemli şartın sağlanması gerekir (Delić ve Bećirović, 2016; Knezic vd., 2010). Bunlar; öğretilecek olan bilgilerin kendi içinde bir bütün oluşturacak biçimde sıralanması ve öğrencilerde konuya yönelik olumlu bir hazırlığın olmasıdır. Yani öğrenci konuyu anlamaya ve bilgiyi keşfetmeye istekli olmalıdır. Bu yöntemde hem öğretmen hem de öğrenci aktif olsa da işi zor olan öğretmendir. Çünkü öğretmen konuları bir bütün olarak sıralama ve örneklemeyle ilgili önceden iyi bir hazırlık yapmakla birlikte dersin yürütülüşü esnasında tartışmaları dikkatle izleyerek öğrencilere rehberlik ederken öğrencilerin konu dışına çıkışını da engellemelidir (Knezic vd., 2010). Ayrıca öğretmenin konuyu buldurmaya istekli olması öğrencilerinde istekli olması için önemlidir (Aydın, 2001). Eğer öğretmen istekli olmaz veya istekli olduğunu sınıfa yansıtamazsa öğrencilerde aktif katılıma karşı isteksizlik oluşur.

Sokratik sorgulama yönteminin planlama ve uygulama aşamasında konuların, kavramlar temelinde bir bütünlük oluşturacak şekilde anlamlı ve sıralı olarak yapılandırılması şarttır. Ancak bu durumda kavramlar ve kavramlar arası ilişkilerin anlaşılması ve yeni bilgilerin elde edilmesi mümkün olacaktır (Lam, 2011). Aksi durumda öğrencinin zihninde bir karışıkık oluşacak, öğretmenin işi zorlaşacak ve ders sıkıcı bir hale gelecektir. Sokratik sorgulama yöntemini derslerinde kullanmak isteyen bir öğretmen, derse başlarken günlük yaşamdan ve öğrencinin ön öğrenmelerini hatırlatan bir soru sorarak derse karşı dikkati çekebilir (Yıldız ve Dadi, 2019). Ayrıca öğrencinin ilgisini derse çekmek amacıyla; konuya başlarken ilginç bir problemin ortaya konulması, örnek bir olayın verilmesi, kısa bir hikâyenin anlatılması, görsellerin ve video gibi öğretim araçlarından faydalanılabilir. Öğrenciler, öğretmenin yönelttiği sorularla, daha önce öğrenmiş oldukları bilgileri ilişkilendirerek çeşitli tahminlerde bulunmaları için teşvik edilir. Bu aşamada önemli olan, sistematik olarak hazırlanmış sorularla öğrenciyi düşünmeye ve hedeflenen yeni bilgileri keşfetmeye yönlendirmektir (Zeybek, 2019). Burada öğrenciler soruları düşünüp cevap verirken çeşitli hatalar yapabilirler. Böyle durumlarda öğretmenler özenle seçtikleri bir örneği vererek veya daha farklı bir soruyu öğrenciye yönelterek öğrencilerin konu dışına çıkması engeller. Böylece öğrencilerin yanlış anlamalarının önüne geçilir, eksikleri tamamlanır ve yeni öğrenilecek bilgiler için temel oluşturulabilir (Chang vd., 1998). Bu yöntemde öğrencilere soru sormanın temel amacı da budur. Öğretmen soru sorarken dersin akıcılığını sağlamak amacıyla sorular arası geçişlerin doğal olmasına, ön konu veya kavram anlaşılmadan bir sonraki kavrama geçilmemesine dikkat etmelidir.

Sokratik sorgulama yöntemi kavram, ilke ve genellemelerin öğretilmesi, kavram yanılgılarının tespit edilmesi ve giderilmesi, daha önce öğrenilen konuların hatırlatılmasında kullanılabilecek önemli bir yöntemdir (Chang vd., 1998; Driver vd., 1998). Bu yöntemde öğretmenin sorularılyla öğrenciler yeni bilgiyi keşfederken ön öğrenmelerini diğer alanlara transfer ederek analiz, sentez ve değerlendirmeler yapar. Bu nedenle öğrenciler bu yöntemi kullanarak bilgi, kavrama, uygulama, analiz, sentez ve değerlendirme seviyesinde öğrenmeler gerçekleştirebilirler (Ertuğrul ve İnan, 2009). Ayrıca yeni bilgileri öğrencilerin kendileri bulduklarından dolayı öğrendikleri daha kalıcı hale gelmektedir. Ayrıca bu yöntemin özendirici, motive edici, düşünmeye sevk edici özelliklerinden dolayı eleştirel düşünme, sorgulama, sözlü ifade, analiz etme, yorumlama becerilerinin gelişmesine önemli katkılar sağlamaktadır (Knezic vd., 2010; Lam, 2011).

Konu öğretiminde sokratik sorgulama yöntemi seçilirken bazı hususlar göz önünde bulundurulmalıdır. Her konu her yöntemle öğretilemediğinden yöntemler seçilirken konu özelliklerine dikkat edilmesi gerekir (Aktaş ve Özmen, 2020). Sokratik sorgulama yönteminin temelinde öğrencilerin daha önce öğrendiği veya günlük yaşamda karşılaştığı bilgilerden hareketle yeni bilgilere ulaşmaları vardır. Bu nedenle öğrencilerin hiç duymadığı, görmediği, bilmediği, hazır bulunuşluklarının olmadığı konuların öğretiminde bu yöntem kullanılamaz (Aydın, 2001). Soyut konuların öğretilmesinde bu yöntemin kullanılması zor olabilir. Bu nedenle öğretmenler, bu yöntemi kullanmadan önce konu seçimini dikkatlice yapmalıdır. Ayrıca yöntem için ideal sınıf mevcudu 30'dur 
(Aydın, 2001). Bu sayıdan fazla mevcudu olan sınıflarda uygulamak zor ve yorucu olabilir. Bu nedenle yöntem seçimi yapılırken sınıf mevcudu dikkate alınmalıdır. Bu yöntem kullanılarak tanım, ilke ve genellemeler öğrencilere hazır bir şekilde verilmediğinden dolayı yeni bilgileri öğrencilere buldurmak uzun zaman alabilir. Bu yöntemi başarılı bir şekilde uygulayabilmek için U şeklinde oturma düzeni veya öğrencilerin ve öğretmenin birbirini rahatça görüp duyabildiği ve iletişim kurabildiği oturuma düzeni sağlanabilir (Yıldız ve Dadi, 2019). Ayrıca bu yöntemde öğretmenin konu bilgisi, sabırlı ve hoşgörülü olması gibi özellikleri de yöntemin başarısı adına önemlidir. Öğrencilerin basit bir bilgiyi bile bulamadıklarında öğretmen sabırlı olmalı ve çeşitli ipuçlarıyla öğrencilerin bilgiyi keşfetmelerini sağlamalıdır (Zeybek, 2019). İlgili literatüre incelediğimizde yöntemin üstün ve zayıf yönlerini Tablo 1'deki gibi özetleyebiliriz (Aydın, 2001; Delić ve Bećirović, 2016; Driver vd., 1998; Knezic vd., 2010; Korkmazer, 2016; Yıldız ve Dadi, 2019; Zeybek, 2019).

Tablo 1.

Sokratik sorgulama yönteminin üstün ve zayıf yönleri

\begin{tabular}{ll}
\hline Üstün Yönleri & Zayıf Yönleri \\
\hline Üst düzey düşünme becerilerini geliştirir. & Uygulaması zaman alır. \\
Ön bilgilerin hatırlanması ve kavramlar arası & Her konuya uygulanamaz. \\
ilişkilerin kurulmasını sağlar. & iyi organize edilmiş ve sıralanmış soruların \\
Analiz sentez değerlendirme için uygundur. & hazırlanması güçtür. \\
Kalıcılığı arttırır. & Öğrencilerin uygun olmayan ve gereksiz cevap \\
Öğrenilenlerin yeni alanlara transfer edilmesini & vermeleri öğretmeni zorlar. \\
sağlar. & Dikkatli kullanılmazsa gürültü ve kargaşa ortamı \\
Arkadaşlarının düšüncelerini dinlemelerini & oluşur. \\
sağlayarak hem onların ne düşündüğünü & Sürekli aynı öğrencilerin cevap vermesi diğer \\
öğrenmelerini hem de onları saygyla dinleme & öğrencileri pasif duruma getirir. \\
alıı̧kanlığı kazandırır. & Soru soran öğretmendir. Yöntemin sadece soru \\
Öğrencilerin sözlü becerilerini geliştirir. & cevap tekniğini içerdiğinin düşünülmesinden dolayı \\
& diğer tekniklere yer verilmemesi dersi sıkıcı hale \\
& getirir. \\
\hline
\end{tabular}

\section{Sokratik sorgulama yöntemi ve fen öğretimi}

Illkokuldan itibaren eğitimin her kademesinde öğretilen fen bilimleri dersinin amacı fen okuryazarı bireyler yetiştirmektir. Fen okuryazarı bireyler, temel fen kavramları hakkında bilgi sahibi olmanın yanında toplumsal sorunların çözümünde kendilerini sorumlu hisseden, eleştirel, yaratıcı düşünme gibi üst düzey düşünme becerilerini kullanarak bu sorunlara çözüm arayan bireylerdir (MEB, 2013). Öğrencilerin fen okuryazarlığını kazanması; çevresini ve toplumu tanımaları, günlük yaşamlarında karşılaştıkları durumları ve olayları anlamaları, özgüven kazanmaları, ilgi ve yeteneklerini geliştirmeleri, bilimsel düşünme ve inceleme alışkanlıkları kazanmaları yönünden önemlidir. Ancak öğrencilerin fen kavramlarını anlama düzeyleri incelendiğinde, fen dersinin soyut kavramlar içermesi, bazı fen kavramların günlük yaşamda bilimsel anlamından farklı kullanılması, öğrencilerin önbilgilerinin eksik olması ve görselleştirme çalışmalarının yetersiz olmasından dolayı öğrenciler eğitimin her seviyesinde fen derslerinde zorlanmaktadır (Aktaş ve Bilgin, 2015; Bilgin, Aktaş ve Çetin, 2014; Özmen, 2011). Özellikle öğrencilerin ön bilgi eksikliği ve sahip olduğu kavram yanılgıları nedeniyle fen başarıları olumsuz yönde etkilenmektedir.

Ortaokul öğrencilerinde sıklıkla karşılan kavram yanılgılarından ve öğrenme güçlüklerinden bazıları; kütle ve ağırlık, ısı ve sıcaklık, çözünme ve erime, hız ve sürat, elektrik akımı, hava ve boşluk, dünya ve güneşin hareketleri, ışık yılı, bağımlı ve bağımsız değişken, homojen ve heterojen karışım, hal değişimi, fotosentez ve solunum, ışık ve ses, bileşik ve karışım, bileşik ve molekül şeklinde sıralanabilir (Aydoğan, Güneş ve Gülçiçek, 2003; Coştu, Ayas ve Ünal, 2007; Ecevit ve Özdemir- 
Şimşek, 2017; Koray ve Tatar, 2003; Kırbulut ve Beeth, 2013; Kırıkkaya ve Güllü, 2008; Yılmazlar, Takunyacı ve Günaydın, 2014). Öğrencilerde var olan kavram yanılgıları onların öğrenme güçlüğü yaşamasına ve başarısızlık hissi yaşayarak özgüvenlerinin kaybolmasına ve bunun sonucunda fen derslerinden uzaklaşmalarına neden olmaktadır (Ayvacı ve Bakırcı, 2018). Bu durum öğrencilerin hem TIMSS, PISA gibi uluslararası sınavlardaki başarılarının, hem LGS gibi ulusal sınavlarındaki başarılarının hem de üniversitelere giriş sınavlarında fen bilimleri başarı ortalamasının düşmesine neden olmaktadır (Bilgin vd., 2014).

Sokratik sorgulama yönteminin kavram yanılgıları ve öğrenme eksikliklerinin giderilmesinde, ayrıca kavramların ilişkilendirilmesinde etkili olmasından dolayı fen derslerinde kullanılmasının oldukça faydalı olacağı düşünülmektedir. Uluslararası alan yazın incelendiğinde sokratik sorgulama yönteminin önemini ve etkisini ortaya koymayı amaçlayan birçok çalışmanın yapılmış olduğu görülmektedir (Chang vd., 1998; Chorzempa ve Lapidus, 2009; Delić ve Bećirović, 2016; Driver vd., 1998; Knezic vd., 2010; Longo, 2007; Pihlgren, 2008; Turnbull ve Mullins, 2007). Ancak Türkiye'de özellikle fen bilimleri derslerine yönelik yapılan çalışma sayısının oldukça sınırlı olduğu görülmektedir (Korkmazer, 2016; Yıldız ve Dadi, 2019; Zeybek, 2019). Türkiye'de yapılan çalışmalar yöntemin okuduğunu anlama becerisi (Epçaçan, 2013), Türkçe programında yönteme ne kadar yer verildiği (Çebi, 2006), din kültürü ve ahlak bilgisi dersinde eleştirel düşünme ve tutuma etkisi (Şişman, 2009), yöntemin önemini ortaya koyma (Çoban, 2016; Ertuğrul ve İnan, 2009), sorgulama becerileri ölçeği geliştirme (Bozer, 2014) üzerine yoğunlaşmıştır. Ayrıca fen bilimleri derslerinde ise lise öğrencilerinin mol kavramı ve avagadro sayısının (Yıldız ve Dadi, 2019), ohm kanununun öğretiminde (Zeybek, 2019) başarı ve kalıcılık üzerine, ortaokul 5. sınıf öğrencilerinde maddenin hal değişiminde başarı (Korkmazer, 2016) etkili olduğunu ortaya koyan çok az sayıda çalışma yürütülmüştür.

Kavram yanılgılarının ve öğrenme eksikliklerinin giderilmesinde etkili olan sokratik sorgulama yönteminin kavram yanılgılarının fazla olduğu fen derslerinde yeteri kadar kullanılmaması ve yapılan çalışmaların sınırlı olması bir eksikliktir. İyi bir hazırıktan sonra fen derslerinde kolaylıkla kullanılabilecek sokratik sorgulama yöntemine dayalı hazırlanan etkinlikler temelinde yöntemin uygulanabilirliğine yönelik bir çalışmanın yapılması hem öğretmenlerde farkındalık oluşturma hem de örnek etkinliklerle fen derslerinde oluşturacağı öğrenme çıktıları ve sınırlııklarını ortaya koyma adına önemli olacaktır. Bu nedenle yürütülen bu çalışmanın amacı sokratik sorgulama yöntemine dayalı geliştirilen fen etkinliklerinin uygulanabilirliğine yönelik öğretmen görüşlerini ortaya koymaktır. Bu genel amaç doğrultusunda alt amaçlar aşağıdaki gibidir;

1. Fen bilimleri öğretmenlerinin sokratik sorgulama yöntemine yönelik bilgi ve yöntemi sınıfta uygulama durumları nasıldır?

2. Fen bilimleri öğretmenlerinin sokratik sorgulama yönteminin fen derslerinde uygulanabilirliğine yönelik görüşleri nelerdir?

3. Fen bilimleri öğretmenlerinin sokratik sorgulama yönteminin öğrenme çıktıları üzerine etkisine yönelik görüşleri nelerdir?

4. Fen bilimleri öğretmenlerinin sokratik sorgulama yönteminin fen derslerinde kullanıldığında karşılaşılacak güçlüklere yönelik görüşleri nelerdir?

5. Fen bilimleri öğretmenlerinin sokratik sorgulama yöntemine dayalı hazırlanan etkinliklere yönelik görüşleri nelerdir? 


\section{Yöntem}

\section{Araştırmanın Yöntemi /Modeli}

Bir veya birden fazla durumla ilgili detaylı açıklama getirmeyi amaçlayan çalışmalarda durum çalışması kullanııı (Creswell, 2014; Özmen ve Karamustafaoğlu, 2019). Bu durum bir olayı, etkinliği veya süreci içerebilir (Yin, 2009). Araştırmacılar özel bir durumdan ziyade belli bir durumdan yola çıkarak daha geneli anlamayı amaçladığı çalışmalarda araçsal durum çalışmalarını tercih ederler (Johnson ve Christensen, 2004). Bu desende araştırmacı durumu bir kuramı test etmek veya önemli gördüğü bazı konu veya sorunları anlamak için kullanabilir. Bu çalışma, sokratik sorgulama yöntemine dayalı geliştirilen fen etkinlikleri temelinde yöntem hakkında deneyimli fen bilimleri öğretmenlerinin görüşlerini belirleyerek yöntemin uygulanabilirliğini ortaya koymayı amaçladığından durum çalışması desenlerinden araçsal durum çalışması desenindedir.

\section{Çalışma Grubu}

Araştırmacılar belli bir konu hakkında derinlemesine bilgi elde etmek istediklerinde araştırmanın özel amacına hizmet edecek gönüllü katılımcılardan oluşan amaçlı örnekleme stratejisini kullanabilirler (Fraenkel, Wallen ve Hyun, 2012). Bu çalışmada fen eğitiminde kullanılabilecek yeni yaklaşımlarla ilgili bilgi düzeyinin yüksek olması ve okullarda öğretim tecrübesi fazla olması nedeniyle çoğunlukla lisansüstü eğitimi olan deneyimli fen bilimleri öğretmenleri tercih edilmiştir. Ayrıca araştırma deseni olarak araçsal durum çalışmasına da uygun olarak öğretmenlerin görev yaptıkları yerleşim yerlerinin de çeşitli olması ve lisansüstü eğitimi olmayan deneyimli öğretmenlerin de katılımcı olarak eklenmesiyle katılımcı grubu zenginleştirilmiştir. Bu bağlamda çalışmanın katılımcılarını amaçsal örneklemeye uygun olarak belirlenen 7 (3 kadın, 4 erkek) fen bilimleri öğretmeni oluşturmuştur. Çalışmaya katılan öğretmenler 7 ile 22 yıl arasında değişen ortalama 14,5 yıllık meslek deneyimine sahiptir. 2 farkıı ilde görev yapan öğretmenlerin yaşları 29 ile 46 arasında değişmekte olup katılımcılar 37 yaş ortalamasına sahiptir. Katılımcı öğretmenlerin altısı eğitim fakültesi fen bilgisi öğretmenliği, biri ise fen-edebiyat fakültesi kimya bölümü mezunu olup fen bilimleri öğretmenliği yapmaktadır. Öğretmenlerden dördü il merkezinde, ikisi ilçe merkezinde ve biri köyde bulunan ortaokullarda çalışmaktadır. Ayrıca öğretmenlerin ikisi doktora eğitimine devam etmekte olup, üçü ise yüksek lisans mezunudur. Katılımcı öğretmenlerin özellikleri incelendiğinde; mesleklerinde oldukça deneyimli oldukları ve eğitim, görev yapılan okul, cinsiyet yönünden heterojen bir yapıya sahip olduğu görülmektedir.

\section{Veri Toplama Araçları ve Süreci}

Öğretmenlerin sokratik sorgulama yöntemine dayalı olarak geliştirilen fen etkinlikleri temelinde yöntemin uygulanabilirliğine yönelik görüşlerini ortaya koymak amacıyla yarı yapılandırılmış görüşmeler kullanılmıştır. Yarı yapılandırılmış görüşme soruları çalışmanın alt amaçları doğrultusunda araştırmacılar tarafından oluşturulduktan sonra kapsam geçerliliğini sağlamak amacıyla 3 fen eğitimcisinin görüşü alınmış ve alınan dönütlere göre gerekli düzeltmeler yapılarak son hali verilmiştir. Yarı yapılandırılmış görüşme soruları 5 temel başlığa yönelik hazırlanmıştır. Birinci başlık fen bilimleri öğretmenlerinin bu çalışmadan önce sokratik sorgulama yöntemi hakkında bilgi durumlarını belirlemeye yöneliktir. İkinci başlık yöntemin fen derslerinde uygulanabilir olup olmadığını ve her konuya uygun olup olmadığını nedenleriyle birlikte belirlemeye yöneliktir. Üçüncü başlık yöntemin öğrencilerin akademik başarı, kalıcılık, derse karşı motivasyon veya düşünme becerileri gibi öğrenme çıktılarına etkisini belirlemeye yöneliktir. Dördüncü başlık yöntemin uygulanması esnasında karşılaşılabilecek güçlüklerin belirlenmesine yöneliktir. Beşinci başlık 
hazırlanan etkinlikler hakkında öğretmen görüşlerini belirlemeye yöneliktir. Yarı yapılandırılmış görüşme soruları Ek-1'de verilmiştir.

Görüşmeler yapılmadan bir hafta önce öğretmenlere araştırmacılar tarafından yöntemi tanıtmak amacıyla hazırlanan bir broşür ve hazırlanan etkinlikler incelemeleri amacıyla verilmiştir. Bu tanıtımın yapılmasının amacı öğretmenlerin sınıfta uyguladıkları tartışma yöntemi veya soru cevap tekniği ile sokratik sorgulama yöntemi arasındaki farklııkları görmelerini sağlamaktır. Aksi durumda sınıfta yapılan basit bir tartışma ile öğretmenler sokratik sorgulama yöntemini uyguladıklarını iddia edebilirlerdi. Yapılan bu tanıtım ile toplanan verilerin güvenirliğinin artııııması amaçlanmıştır. Öğretmenler yöntem hakkında yeterli bilgiye sahip olduktan sonra görüşmeler yürütülmüştür. Her öğretmen ile 30 ile 40 dakika arasında süren birer görüşme gerçekleştirilmiştir. Yarı yapılandırılmış görüşmeler birinci araştırmacı tarafından 6 öğretmen ile yüz yüze, bir öğretmenle ise diğer bir ilde olduğundan telefon ile yapılmıştır. Görüşmeler sesli olarak kayıt altına alınmıştır. Bu ses kayıtları görüşmelerden sonra öğretmenlerle paylaşılarak sorulara verdikleri cevaplarda herhangi bir değişiklik yapmayı isteyip istemedikleri sorulmuştur. Öğretmenlerden gelen dönütlerden sonra görüşmeler transkript edilerek analiz aşamasına geçilmiştir.

\section{Etkinliklerin Geliştirilme Süreci}

Bu çalışmada sokratik sorgulama yöntemine dayalı farklı sınıf seviyelerine yönelik toplam dört adet fen etkinliği geliştirilmiştir. Bunlardan ilki 5. sınıf ünitelerinden hal değişimi konusuna yöneliktir. Öğrencilerin hal değişimi konusunda sahip olduğu kavram yanılgılarının fazla olması nedeniyle bu konu seçilmiştir. Bu konuda öğrencilerde en fazla rastlanan kavram yanılgıları; maddelerin hal değiştirirken katı, sıvı, gaz sırasından şaşmayarak hal değiştireceğine inanılması, kaynama ile buharlaşmanın karıştırılması ve hangi hal değişimlerinde ısı alıp verilme durumlarının karıştırılmasıdır (Çelikler ve Kaya, 2016; Gökulu, 2015; Sarı-Ay ve Aydoğdu, 2015). Geliştirilen ikinci etkinlik 6. sınıf ünitelerinden sesin iletimi konusuna yöneliktir. Bu konuda 6 . sınıf öğrencilerinin sıklıkla yaşadığı kavram yanılgıları; sesin katı ve sıvı ortamlarda iletilmediği, sesin iletim hızının ortama bağlı olmadığı, sesin boşlukta iletildiği, müzik aletlerini farklı kişiler çaldığı için farklı sesler duyulduğu, müzik aletlerinin çalındığı ortamın seslerin farklı şekilde duyulmasında etkili olduğu ve sesin farklı kişiler tarafından farklı duyulduğunun düşünülmesidir (Ayvacı ve Bakırcı, 2018; Bostan-Sarıoğlan, 2016). Geliştirilen üçüncü etkinlik 7. sınıf ünitelerinden maddenin tanecikli yapısı konularına yöneliktir. Bu konuda 7. sınıf öğrencilerinin sıklıkla yaşadığı kavram yanılgıları; bileşik ile molekül, bileşik ile karışım, element ile molekül kavramlarının birbirinin yerine kullanılması; atom, molekül, element ve bileşik arasındaki ilişki ve farkların karıştırııması ve bunların modellerini ayırt etmede öğrenme güçlüklerinin yaşanmasıdır (Benlikaya, 2018; Dolu, 2018). Geliştirilen dördüncü etkinlik 8. sınıf ünitelerinden asitler ve bazlar konularına yöneliktir. Bu konuda 8. sınıf öğrencilerinin sıklıkla yaşadığı kavram yanılgıları; $\mathrm{H}+$ (veya $\mathrm{H}=$ Hidrojen) iyonu içeren her maddeye asit denildiği, bazların yapısında $\mathrm{OH}$ - (veya $\mathrm{OH}$ ) iyonunun mutlaka bulunması gerektiği, asitlerin bazlardan daha zehirli olduğu, asitlerin metalleri ve her şeyi erittiğidir (Pabuçcu ve Geban, 2015).

Öğrencilerde var olan bu kavram yanılgıları kavram kargaşasına ve öğrenme güçlüklerinin yaşanmasına neden olmaktadır. Kavram yanılgılarının giderilmesinde ve kavram bütünlüğünün oluşturulmasında öğrencileri aktif hale getiren ve bilgiyi buldurmasını sağlayan sokratik sorgulama yöntemi oldukça etkilidir. Bu nedenle öğrencilerin aktif katılımlarının sağlanarak günlük yaşam olayları temelinde oluşturulacak sokratik sorgulama etkinliklerinin bu kavram yanılgılarını gidermede ve kavramların ilişkilendirilmesinde etkili olacağı düşünüldüğünden belirtilen bu dört konu seçilmiştir.

Etkinliklerin geliştirilme sürecinde beş aşamadan oluşan sistematik bir yol izlenmiştir. Bu aşamalar ve her bir aşamada neler yapıldığı aşağıdaki gibidir; 
Literatür taraması: Öncelikle ilgili literatür taraması yapılarak ortaokul öğrencilerinin sahip olduğu kavram yanılgıları ve öğrenme güçlükleri tespit edilmiştir. Tespit edilen kavram yanılgıları ve öğrenme güçlükleri çerçevesinde sokratik sorgulama yöntemiyle sunulacak konuların sınırları belirlenmiştir. Belirlenen kavram yanılgıları yukarıda belirtilmiştir.

Sokratik sorgulama sorularının hazırlanması: Tespit edilen ve kapsamı belirlenen kavram yanılgıları ve öğrenme güçlükleri ile ilgi sorgulama soruları hazırlanmıştır. Sorular mümkün olduğu kadar günlük yaşamla ve ön öğrenmelerle ilişkilendirilmiştir. Ayrıca sorularda basitten başlanarak karmaşığa doğru bir sıra izlenmiştir.

Sorulara yönelik öğrencilerden gelecek muhtemel cevapların alınması: Basitten karmaşığa doğru organize edilen sorular, her sınıf düzeyinden seçilen üçer öğrenciye sorularak öğrencilerden gelebilecek muhtemel cevaplar oluşturulmuştur. Bu cevapların oluşturulmasında araştırmacılar, kendi ders sunumlarındaki deneyimleri doğrultusunda öğrencilerin vermiş olduğu cevapları da dikkate almıştır.

Sistematik soru cevap diyalogların oluşturulması: Alınan muhtemel cevaplara karşılık olarak öğrencileri bilgiye ulaştıracak, onları bilgiyi keşfetmeye yönlendirecek yeni sorular araştırmacılar tarafından hazırlanmıştır. Böylece her bir kavram için öğrenciye doğru bilgiyi bulduracak diyaloglar oluşturulmuştur.

Öğretmen görüşlerinin alınması: Son olarak geliştirilen diyalogların öğrencilerin özelliklerine uyup uymadığı, tartışma ortamının sağlanıp sağlanamayacağı, öğrenciye bilgiyi buldurmak, kavram yanılgılarını ve öğrenme güçlüklerini ortadan kaldırmak için yeterli olup olmadığı gibi özelliklerini belirlemek amacıyla öğretmen görüşleri alınmıştır. Öğretmenlerin görüşleri doğrultusunda gerekli düzeltmeler yapıldıktan sonra sokratik sorgulama diyaloglarına son hali verilmiştir. Geliştirilen sokratik sorgulama etkinlikleri Ek-2'de verilmiştir.

Verilerin Analizi: Yarı yapılandırılmış görüşme verileri inandırıcılığı arttırmak amacıyla iki kodlayıcı tarafından içerik analizi tekniği kullanılarak analiz edilmiş ve bulgular bölümünde sunulmuştur (Yıldırım ve Şimşek, 2011). Öncelikle, 2 kodlayıcının bir araya gelmesiyle en fazla görüş bildiren öğretmene ait veriler arasından anlamlı veriler ayıklanarak kodlanmış ve kategorilere ayrımıştır. Sonra, iki kodlayıcı ayrı ayrı diğer öğretmenlerin verilerini kodlayarak kategorilere ayırmışır. Daha sonra, iki kodlayıcı tarafından aynı şekilde ve farklı şekilde yapılan kodlamalar belirlenmiştir. Ö1 ile kodlanan öğretmenin verileri birlikte analiz edildiğinden dolayı Ö1 hariç tutulduğunda ayıklanan anlamlı cümle olarak toplamda öğretmenler 176 adet görüş belirtmiştir. íki kodlayıcı bu görüşlerin 159 tanesini aynı şekilde, 17 tanesini ise farkı şekilde kodlamıştır. Kodlayıcıların kodlamaları arasındaki uyumluluk katsayısı Miles ve Huberman (1994) tarafından geliştirilen (uyum sağlanan kod sayısı / toplam kod sayısı) formülü kullanılarak hesaplanmış ve $\approx 0,90$ olarak bulunmuştur. Son olarak, kodlayıcılar tarafından farklı şekilde kodlanan görüşler kodlayıcıların bir araya gelerek fikir birliğine varmasıyla yeniden kodlanmıştır.

\section{Bulgular}

Yarı yapılandırımış görüşmelerden elde edilen veriler çalışmanın amaçları doğrultusunda; öğretmenlerin bu çalışmadan önce sokratik sorgulama yöntemi hakkındaki bilgi ve yöntemi uygulama durumları, sokratik sorgulama yönteminin fen derslerin de uygulanabilirliği, yöntemin öğrencilerin öğrenme çıktıları üzerine etkileri, yöntemin uygulanması esnasında karşılaşılabilecek güçlükler ve hazırlanan etkinlikler hakkında görüşler olmak üzere beş başlık olarak sunulmuştur. 


\section{Öğretmenlerin çalışma öncesinde sokratik sorgulama yöntemi hakkındaki bilgi durumları}

Fen bilimleri öğretmenleri ile yapılan yarı yapılandırılmış görüşmelerden elde edilen verilerin içerik analizine tabi tutulmasıyla ulaşılan öğretmenlerin bu çalışmadan önce sokratik sorgulama yöntemi hakkındaki bilgi durumlarına yönelik bulgular Tablo 2'de verilmiştir.

Tablo 2.

Öğretmenlerin sokratik sorgulama yöntemi hakkındaki bilgileri

\begin{tabular}{|c|c|c|c|c|c|c|c|c|}
\hline Kategori & Görüşler & $: \overline{0}$ & : & 0 & $: 0$ & $: 0$ & :̊ & : \\
\hline \multirow{6}{*}{$\begin{array}{l}\text { Bilgi } \\
\text { Durumu }\end{array}$} & Daha önce bilgim yoktu. & & $\checkmark$ & $\checkmark$ & & & & \\
\hline & Daha önce kısmen bilgim vardı. & $\checkmark$ & & & $\checkmark$ & $\checkmark$ & $\checkmark$ & $\checkmark$ \\
\hline & Soru cevap bölümünü derslerimde kullanıyorum. & $\checkmark$ & $\checkmark$ & & $\checkmark$ & $\checkmark$ & $\checkmark$ & \\
\hline & Buluş yolunu kısmen derslerimde kullanıyorum. & $\checkmark$ & & $\checkmark$ & $\checkmark$ & & & $\checkmark$ \\
\hline & Bu kadar sistematik ve adımlarıyla kullanmıyorum. & $\checkmark$ & $\checkmark$ & $\checkmark$ & $\checkmark$ & $\checkmark$ & $\checkmark$ & \\
\hline & Şimdi adımlarıyla birlikte bilgi sahibiyim. & $\checkmark$ & $\checkmark$ & $\checkmark$ & $\checkmark$ & $\checkmark$ & $\checkmark$ & $\checkmark$ \\
\hline
\end{tabular}

Bu çalışma öncesinde bazı fen bilimleri öğretmenlerinin yöntem hakkında bilgileri yokken bazı öğretmenlerin ise yöntemin ismini duyma noktasında kısmen bilgilerinin olduğu tespit edilmiştir. Sokratik sorgulama yöntemi materyallerini inceledikten sonra ise bazı öğretmenler soru cevap yöntemini bazı öğretmenler buldurma yöntemini derslerinde kullandıklarını, ancak bu yöntemdeki bilmediğini hissetme aşaması ve sistematik soruları kullanmadıklarını ifade etmiştir. Görüşmeler yapılmadan önce ise yöntem hakkında yeterli bilgiyi elde ettiklerini ifade etmiştir. Bu ifadeler doğrultusunda öğretmenler tarafından yöntemin yeteri kadar bilinmediği ancak kullandıkları yöntemlerle ilişkili olduğu söylenebilir.

\section{Yöntemin fen bilimleri derslerinde uygulanabilirliğine yönelik görüşler}

Fen bilimleri öğretmenlerinin sokratik sorgulama yönteminin fen bilimleri derslerinde uygulanabilirliğine yönelik görüşlerine ait bulgular Tablo 3'te verilmiştir.

Tablo 3.

Yöntemin fen bilimleri derslerinde uygulanabilirliğine yönelik görüşler

\begin{tabular}{|c|c|c|c|c|c|c|c|}
\hline $\begin{array}{l}\text { Kate- } \\
\text { gori }\end{array}$ & Görüşler & 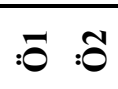 & 0 & $: 0$ & $: 0$ & : & : \\
\hline \multirow{11}{*}{ 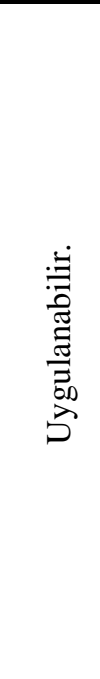 } & Fen günlük yaşamla çok fazla ilişkili olduğundan ve yöntem günlük & ل & $\checkmark$ & $\checkmark$ & $\checkmark$ & & ব \\
\hline & yaşamı yansıtan sorularla başladığından uygulanabilir. & & & & & & \\
\hline & $\begin{array}{l}\text { Fen dersinde kavram yanılgıları fazla olduğu ve yöntem kavram } \\
\text { yanılgılarını gidermede etkili olduğundan uygulanabilir. }\end{array}$ & $\checkmark \checkmark$ & $\checkmark$ & $\checkmark$ & & $\checkmark$ & $\checkmark$ \\
\hline & $\begin{array}{l}\text { Öğretim programı sorgulamaya dayalı yöntemlere vurgu yaptığından } \\
\text { ve yöntem sorgulamaya dayalı olduğundan uygulanabilir. }\end{array}$ & $\checkmark$ & & $\checkmark$ & 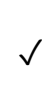 & d & $\checkmark$ \\
\hline & $\begin{array}{l}\text { Öğrencilerin karıştırdığı kavramların öğretimine uygun olduğundan } \\
\text { uygulanabilir. }\end{array}$ & $\checkmark \checkmark$ & & $\checkmark$ & & & $\checkmark$ \\
\hline & 5 sınıflardan 8 sinıflara doğru gidildikçe daha kolay uygulanır. & $\checkmark$ & $\checkmark$ & & $\checkmark$ & & $\checkmark$ \\
\hline & 5-8 her sinıf düzeyinde uygulanabilir. & & & $v$ & $\checkmark$ & $v$ & \\
\hline & $\begin{array}{l}\text { 5E, PDÖ gibi yenilikçi yöntemlerle karşılaştırıldığında sınıflarda daha } \\
\text { rahat uygulanır. }\end{array}$ & $\checkmark$ & & $\checkmark$ & 1 & & \\
\hline & Öğrencilerin ön öğrenmelerinin olduğu konularda uygulanabilir & & & $\checkmark$ & $\checkmark$ & & \\
\hline & $\begin{array}{l}\text { Yöntemin uygulanmasında çok fazla araç gerece ihtiyaç } \\
\text { duyulmadığından uygulanabilir. }\end{array}$ & & & & & & \\
\hline & Sosyo-bilimsel konularda oldukça etkili bir şekilde uygulanabilir. & & & & & $\checkmark$ & \\
\hline
\end{tabular}




\begin{tabular}{|c|c|c|c|c|c|c|c|c|}
\hline $\begin{array}{l}\text { Kate- } \\
\text { gori }\end{array}$ & Görüşler & $\overline{0}$ & : & 0 & $: 0$ & $: 0$ & : & : \\
\hline \multirow{11}{*}{ 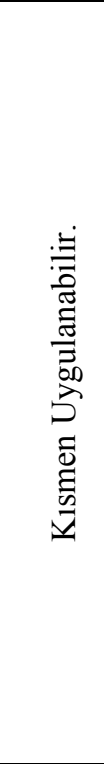 } & Soyut konularda video, basit deney gibi etkinliklerle desteklenmelidir. & $\bar{\checkmark}$ & & $\bar{\checkmark}$ & $\bar{V}$ & & $\bar{\checkmark}$ & $\bar{\checkmark}$ \\
\hline & Soyut konuların öğretiminde uygulanması güçlük yaşanabilir. & & & $\checkmark$ & $\checkmark$ & $\checkmark$ & & $\checkmark$ \\
\hline & $\begin{array}{l}\text { Kavram sayısının fazla olduğu konularda uygulanırken güçlük } \\
\text { yaşanabilir (Mitoz mayoz bölünme gibi). }\end{array}$ & & $\checkmark$ & $\checkmark$ & & & & $\checkmark$ \\
\hline & $\begin{array}{l}5 \text { sinıflar bize daha fazla soru sorduğundan uygulanırken güçlük } \\
\text { yaşanabilir. }\end{array}$ & & & $\checkmark$ & & $\checkmark$ & & $\checkmark$ \\
\hline & Kavramların tanımları verilirken uygulanması güçlük yaşanabilir. & & & $\checkmark$ & $\checkmark$ & & & \\
\hline & $\begin{array}{l}\text { Bağıntı (formül) verilmesi gereken konularda uygulanırken güçlük } \\
\text { yaşanabilir. }\end{array}$ & & & $\checkmark$ & $\checkmark$ & & & \\
\hline & Ünitenin tamamında kullanılmaz. & & & & $\checkmark$ & & $\checkmark$ & \\
\hline & $\begin{array}{l}\text { Akademik veya hazır bulunuşluk yönünden heterojen sınıflarda } \\
\text { uygulanırken güçlük yaşanabilir. }\end{array}$ & $\checkmark$ & & & & $\checkmark$ & & \\
\hline & $\begin{array}{l}\text { Ön öğrenmelerin eksik olduğu konularda uygulanırken güçlük } \\
\text { yaşanabilir. }\end{array}$ & & & & & $\checkmark$ & & 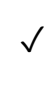 \\
\hline & $\begin{array}{l}\text { Günlük yaşamla ilişkili olmayan konuların öğretiminde güçlük } \\
\text { yaşanabilir. }\end{array}$ & & & & & $\checkmark$ & & \\
\hline & $\begin{array}{l}\text { Psikomotor becerisi gerektiren konuların öğretiminde uygulanırken } \\
\text { güçlük yaşanabilir. }\end{array}$ & & & & & & $\checkmark$ & \\
\hline
\end{tabular}

Öğretmenler sokratik sorgulama yönteminin fen bilimleri derslerinde uygulanabilirliğine yönelik olarak konu, kavramlar ve yöntemin aşamalarını dikkate aldıklarında uygulanabilir ve kısmen uygulanabilir şeklinde iki kategoride görüş belirtmişlerdir. Yöntemin fen bilimleri derslerinde uygulanabilirliğine yönelik tüm öğretmenler fen bilimleri dersinin çok fazla günlük hayatla ilişkili olması ve yöntemin günlük yaşam olaylarını içeren sorular veya örnek olaylarla başlaması, fen bilimleri derslerinde kavram yanılgılarının ve karıştırdıkları kavramların çok fazla olması ve yöntemin kavram yanılgılarını gidermede etkili olacağını düşündüklerinden dolayı uygulanabilir olduğunu ifade etmiştir. Fen bilimleri öğretim programının sorgulama stratejisi üzerine vurgu yapması ve yöntemin buldurma aşamasının bu amaca çok fazla hizmet edeceği düşünceleriyle uygulanabilir olduğu ifadelerini desteklemiştir. Ayrıca bazı öğretmenler 5-8 tüm sınıf düzeyinde rahatlıkla uygulanabileceğini ifade ederken bazı öğretmenler buna ilave olarak 5'ten 8 sınıfa doğru gidildikçe daha rahat uygulanabileceğini ifade etmiştir. Öğretmenlerden bazıları $5 \mathrm{E}$, probleme dayalı öğrenme gibi diğer yöntemlerle karşılaştırıldığında daha rahat uygulanabileceğini ifade etmiştir. Ön öğrenmelerin etkili olması, programın sarmal yapısı, fazla araç gerece ihtiyaç duyulmaması ve sosyobilimsel konuların doğasına uygun olması nedeniyle uygulanabilir olduğunu ifade etmiştir.

Fen bilimleri öğretmenleri soyut konuların, kavram sayısının fazla olduğu konuların, kavram tanımlarının, formül gerektiren konuların öğretiminde güçlük yaşanabileceği ve bu nedenle görsel, basit deney gibi etkinlikle zenginleştirilmesi gerektiği nedenlerinden kısmen uygulanabilir olduğunu ifade etmiştir. 5. sınıf öğrencilerinin gelişim özelliklerinden dolayı öğrencilerin daha çok soru sorması, akademik yönden heterojen olan sınıflarda seviye farkından ve ön öğrenme eksiklerinin olabileceği nedenlerinden dolayı kısmen uygulanabilir olduğunu ifade etmiştir.

\section{Yöntemin öğrencilerin öğrenme çıktıları üzerine etkilerine yönelik görüşleri}

Fen bilimleri öğretmenleri sokratik sorgulama yönteminin öğrencilerin öğrenme çıktıları üzerine etkilerine yönelik görüşleri akademik başarı, kalıcılık, motivasyon, üst düzey düşünme becerileri, iletişim becerisi ve aktif katılım kategorilerinde incelenmiştir. Bu kategoriler altında öğretmen görüşlerine ait bulgular Tablo 4'te verilmiştir. 
Tablo 4.

Yöntemin öğrencilerin öğrenme çıktıları üzerine etkisine yönelik görüşler

\begin{tabular}{|c|c|c|c|c|c|c|c|c|}
\hline Kategori & Görüşler & $\overline{0}$ & ฮี & 0 & : & $: 0$ & @̊ & $\hat{0}$ \\
\hline \multirow{3}{*}{ Başarı artar. } & Öğrenci bilgiyi kendisi buluyor. & $\sqrt{ }$ & $\checkmark$ & $\checkmark$ & $\checkmark$ & $\sqrt{ }$ & $\sqrt{ }$ & $\checkmark$ \\
\hline & $\begin{array}{l}\text { Öğrencinin yanlış bildiğini hissettikten sonra doğrusunu } \\
\text { öğrenmesi bașarıyı arttırır. }\end{array}$ & $\checkmark$ & $\checkmark$ & & $\checkmark$ & & $\checkmark$ & $\checkmark$ \\
\hline & $\begin{array}{l}\text { Özetlemeler bilgiyi zihninde toparlamasını sağlayacağı için } \\
\text { başarı artar. }\end{array}$ & $\checkmark$ & & & $\checkmark$ & & & $\checkmark$ \\
\hline \multirow{3}{*}{ Kalıcılık artar. } & Öğrenci bilgiyi kendisi buluyor. & $\sqrt{ }$ & $\checkmark$ & $\checkmark$ & $\sqrt{ }$ & $\sqrt{ }$ & $\sqrt{ }$ & $\bar{\checkmark}$ \\
\hline & $\begin{array}{l}\text { Öğrencinin yanlış bildiğini hissettikten sonra doğrusunu } \\
\text { öğrenmesi kalıcılığı arttırır. }\end{array}$ & $\checkmark$ & & & $\checkmark$ & & $\checkmark$ & $\checkmark$ \\
\hline & Belli aralıklarla özetlemelerin yapılması kalıcılığını artırır. & & & $\checkmark$ & & & & \\
\hline \multirow{4}{*}{$\begin{array}{l}\text { Motivasyon } \\
\text { artar. }\end{array}$} & $\begin{array}{l}\text { Günlük yaşam olaylarına yönelik sorular öğrencilerin derse } \\
\text { istekli katılımını sağlar. }\end{array}$ & $\checkmark$ & & & $\checkmark$ & $\checkmark$ & & $\checkmark$ \\
\hline & $\begin{array}{l}\text { Yanlış cevap verse bile bunun yöntemde bir öğrenme } \\
\text { basamağı olduğunu bildiğinden dolayı bozulmayacak. }\end{array}$ & $\checkmark$ & & $\checkmark$ & $\checkmark$ & $\checkmark$ & & \\
\hline & $\begin{array}{l}\text { Bilimsel cevaplar gerektirmediğinden dolayı öğrenciler } \\
\text { katılmaya istekli olur. }\end{array}$ & $\checkmark$ & & & $\checkmark$ & $\checkmark$ & & \\
\hline & $\begin{array}{l}\text { Bilmediğini hissettiğinde daha meraklı bir şekilde dersi } \\
\text { dinleyecek. }\end{array}$ & & $\checkmark$ & & & & & \\
\hline \multirow{3}{*}{$\begin{array}{l}\text { Üst düzey } \\
\text { düşünme } \\
\text { becerileri } \\
\text { artar. }\end{array}$} & $\begin{array}{l}\text { Sistematik sorular bir sonraki soruyu düşünmelerini, analiz } \\
\text { etmelerini sağlayacaktır. }\end{array}$ & $\checkmark$ & $\checkmark$ & $\checkmark$ & $\checkmark$ & & $\checkmark$ & \\
\hline & $\begin{array}{l}\text { Arkadaşları ile kendi düşüncelerini karşılaştırarak fikir } \\
\text { üretmeye başlar. }\end{array}$ & & & & $\checkmark$ & & $\checkmark$ & $\checkmark$ \\
\hline & Soruları cevaplamak için çok yönlü düşünecekler. & $\checkmark$ & & & & & $\checkmark$ & \\
\hline \multirow{3}{*}{$\begin{array}{l}\text { İletişim } \\
\text { becerisi artar. }\end{array}$} & Karşılıklı soru cevaplar, diyaloglar olacak. & $\checkmark$ & & $\checkmark$ & $\checkmark$ & $\checkmark$ & & $\checkmark$ \\
\hline & Karşıdakini dinleme alışkanlığı kazandırır. & & & $\checkmark$ & $\checkmark$ & $\checkmark$ & $\checkmark$ & $\checkmark$ \\
\hline & $\begin{array}{l}\text { Kendi düşüncelerini karşıdakinin anlayabileceği şekilde ifade } \\
\text { etmeye çalışacaktır. }\end{array}$ & & & & & & $\checkmark$ & $\sqrt{ }$ \\
\hline \multirow{3}{*}{$\begin{array}{l}\text { Aktif katılim } \\
\text { artar. }\end{array}$} & $\begin{array}{l}\text { Bilimsel tanım yapamasa da günlük yaşamından basit } \\
\text { örneklerle katılacaktır. }\end{array}$ & $\checkmark$ & & & $\checkmark$ & $\checkmark$ & & d \\
\hline & $\begin{array}{l}\text { Sistematik sorular sorulduğundan dolayı sürekli aktif katılımı } \\
\text { sağlar. }\end{array}$ & & & $\checkmark$ & & & $\checkmark$ & $\checkmark$ \\
\hline & $\begin{array}{l}\text { Herkesin katılımını gören öğrenci kendi de derse katılmak } \\
\text { ister. }\end{array}$ & & & & $\checkmark$ & $v$ & $\checkmark$ & \\
\hline
\end{tabular}

Fen bilimleri öğretmenleri sokratik sorgulama yönteminin derslerde uygulandığında öğrencilerin akademik başarılarını, kalıcılık, motivasyon, üst düzey düşünme becerileri, iletişim becerisi ve aktif katılımlarını arttıracağını ifade etmiştir. Öğretmenler öğrencilerinin bilgiyi kendilerinin bulmaları, bilmediğini hissettirme aşamasında yanlış bildiklerini hissettikten sonra konu veya kavramların doğrusunu öğrenmesi ve özetleme aşamalarının bilgiyi toparlamalarını sağlaması nedeniyle başarı ve kalııılığı arttıracağını ifade etmiştir. Günlük yaşam olaylarına yönelik sorularla başlanmasının öğrencinin yaşantısında olan durumları sorgulaması, sorulara yanlış cevap verse bile bunun yöntemin bir adımı olduğunu bilmesi, bilimsel cevapların gerektirmemesi ve bilmediğini hissettiğinde doğrusunu öğrenme dürtüsü nedeniyle öğrencilerinin motivasyonunu arttıracağını ifade etmiş̧ir. Soruların sistematik olarak sorulması bir sonraki soruyu düşünmelerine analiz etmelerini sağlaması, arkadaşları ile kendi düşüncelerini karşılaştırmaya fırsat bulmaları ve soruları çok yönlü düşünmeleri nedeniyle üst düzey düşünme becerilerini arttıracağını ifade etmiştir. Karşılıklı soru cevapların ve diyalogların olması, kendi düşüncelerini karşıdakinin anlayabileceği şekilde ifade etme gerekliliği ve karşıdakini dinleme alışkanlığının kazanılması nedeniyle iletişim becerilerinin artacağını ifade etmiştir. Bilimsel olmasa da günlük yaşamından basit örneklerin, sistematik soruların devamlılı̆ı sağlaması ve katılmayan öğrencilerin katılanlardan cesaret alması nedeniyle yöntemin aktif katılımı arttıracağını ifade etmiştir. 


\section{Yöntemin uygulanması esnasında karşılaşılabilecek güçlüklere yönelik görüşler}

Fen bilimleri öğretmenlerinin sokratik sorgulama yönteminin uygulanması esnasında karşılaşılabilecek güçlükleri öğrenci cevapları, öğretmen yeterliliği, zaman, sınıf mevcudu, uzun süreli kullanım ve diğer kategorilerinde incelenmiştir. Bu kategoriler altında öğretmen görüşlerine ait bulgular Tablo 5'te verilmiştir.

Tablo 5.

Yöntemin uygulanması esnasında karşılaşılabilecek güçlüklere yönelik görüşler

\begin{tabular}{|c|c|c|c|c|c|c|c|c|}
\hline Kategori & Görüşler & $\overline{0}$ & : & 0 & $:$ & : & ๑̊ & $\hat{0}$ \\
\hline \multirow{5}{*}{$\begin{array}{l}\text { Öğrenci } \\
\text { cevapları süreci } \\
\text { etkiler. }\end{array}$} & Sürekli aynı öğrencilerden cevap gelebilir. & $\checkmark$ & $\checkmark$ & $\sqrt{ }$ & $\checkmark$ & $\checkmark$ & & $\bar{\checkmark}$ \\
\hline & Derse katılmayanlar cevap vermeyebilirler. & $\checkmark$ & & $\checkmark$ & & $\checkmark$ & $\checkmark$ & $\checkmark$ \\
\hline & Öğrenciler bazen beklenen cevabı veremeyebilirler. & $\checkmark$ & & $\checkmark$ & $\checkmark$ & & & $\checkmark$ \\
\hline & Farklı yönde cevap gelince konu dağılabilir. & $\checkmark$ & & & & $\checkmark$ & & \\
\hline & $\begin{array}{l}\text { Öğrenciler cevaplarıyla beklendiği kadar tartışmaya } \\
\text { katılamayabilir. }\end{array}$ & & & & $\checkmark$ & & $\checkmark$ & \\
\hline \multirow{4}{*}{$\begin{array}{l}\text { Öğretmen } \\
\text { yeterliliği }\end{array}$} & $\begin{array}{l}\text { Sistematik ve etkili soru hazırlama ve sormada } \\
\text { zorlanabilir. }\end{array}$ & $\checkmark$ & & $\checkmark$ & $\checkmark$ & $\checkmark$ & $\checkmark$ & \\
\hline & $\begin{array}{l}\text { İyi bir alan ve pedagoji bilgisine sahip olmayan yöntemi } \\
\text { ilerletmekte sıkıntı yaşayabilir. }\end{array}$ & & & & $\checkmark$ & $\checkmark$ & $\checkmark$ & $\checkmark$ \\
\hline & $\begin{array}{l}\text { Her öğrencinin cevap vermeye çalışması karmaşaya neden } \\
\text { olabilir. }\end{array}$ & & $\checkmark$ & $\checkmark$ & & & & \\
\hline & Yöntemi içselleştirmemişse uygulamada sıkıntılar yaşanır. & & & $\checkmark$ & $\checkmark$ & & & \\
\hline Sinif mevcudu & 25-30 kişiyi aşan sinıflarda uygulamak zor olur. & $\checkmark$ & $\checkmark$ & & $\checkmark$ & $\checkmark$ & & \\
\hline Zaman & $\begin{array}{l}\text { Bütün öğrencilerde cevap alınmaya çalışıldığında zaman } \\
\text { sıkıntısı yaşanır. }\end{array}$ & $\checkmark$ & $\checkmark$ & & $\checkmark$ & $\checkmark$ & & \\
\hline \multirow{2}{*}{$\begin{array}{l}\text { Uzun süreli } \\
\text { kullanım sıkıcı } \\
\text { olur. }\end{array}$} & $\begin{array}{l}\text { Yöntemin uzun süreli kullanılması öğrencilerin } \\
\text { sıkılmasına neden olabilir. }\end{array}$ & $\checkmark$ & & & & $\checkmark$ & $\checkmark$ & $\checkmark$ \\
\hline & Video basit deney gibi etkinliklerle desteklenmelidir. & $\checkmark$ & & & & & & $\checkmark$ \\
\hline \multirow{2}{*}{ Diğer } & Sınıftaki öğrenci seviyeleri birbirine yakın olmalı & $\checkmark$ & & $\checkmark$ & & & & \\
\hline & Öğrenciler not almaya firsat bulamayabilirler. & & & & & & & $\checkmark$ \\
\hline
\end{tabular}

Fen bilimleri öğretmenleri sokratik sorgulama yönteminin derslerde uygulanması esnasında öğrenci cevapları ve öğretmen yeterliliğinin süreci etkilemesi, zaman, sınıf mevcudu sınırlııkları, uzun süreli kullanım süreci sıkıcı hale getirmesi ve diğer nedenlerden dolayı güçlük yaşanabileceğini ifade etmiştir. Öğretmenler sürekli aynı öğrencilerin cevap vermesi ve geri planda kalan öğrencilerin cevap vermemesi, bazen beklenen cevabın verilmemesi veya farklı yönde cevap gelmesiyle konunun dağılması ve öğrencilerin cevaplarıyla istenen tartışma ortamının oluşmaması gibi öğrenci cevaplarından kaynaklanan nedenlerden dolayı öğretmenlerin güçlük yaşayabileceğini ifade etmiştir. Öğretmenler ayrıca, öğretmenin sistematik soru ve etkili sorular hazırlayamaması ve soramaması, alan ve pedagoji bilgisindeki eksiklikler, her öğrencinin cevap verme isteğiyle oluşacak karmaşa ortamını yönetememesi ve yönteme tam anlamıyla hâkim olmaması gibi öğretmen yeterliliğinden kaynaklanan güçlükler yaşanabileceğini ifade etmiştir. Sınıf mevcudunun kalabalık olması, bütün öğrencilerden cevap alınmaya çalışıldığında zaman konusunda sıkıntı yaşanacağını ifade etmiştir. Yöntemin uzun süreli kullanıldığında ve video ve basit deneylerle desteklenmediğinde öğrencilerin sıkılabileceğini ifade etmiştir. Öğrenci seviyeleri birbirine yakın olmadığında zorluk yaşanabileceğini ve öğrencilerin not tutmaya fırsat bulamayacağı gibi güçlüklerinde yaşanabileceğini ifade etmiştir. 


\section{Sokratik sorgulama yöntemine dayalı fen etkinlikleri hakkında görüşler}

Araştırmacılar tarafından sokratik sorgulama yöntemine dayalı hazırlanan fen etkinliklerine yönelik öğretmen görüşleri kazanımlarla ilişki düzeyi, kapsam yeterliliği soruların sistematikliği, uygulanabilirliği ve yapılan etkinliklerin adımlara uygunluğu maddelerine göre değerlendirilmiştir. Öğretmenlerden her bir maddeye 1 ile 3 arasında puan vermeleri istenmiştir. Öğretmenlerin her bir etkinliğe yönelik puanlamaları Tablo 6'da verilmiştir.

Tablo 6.

Geliştirilen fen etkinliklerine yönelik görüşler

\begin{tabular}{|c|c|c|c|c|c|c|c|c|}
\hline Etkinlik & Görüşler & $\overline{0}$ & $: 0$ & $\hat{0}$ & : & $\because$ & : & $\hat{0}$ \\
\hline \multirow{5}{*}{$\begin{array}{c}\text { 5. Sinif } \\
\text { Maddenin Halleri }\end{array}$} & Kazanımlarla ilisski düzeyi & 3 & 3 & 3 & 3 & 3 & 3 & 3 \\
\hline & Kapsam yeterliliği & 3 & 3 & 3 & 3 & 3 & 3 & 3 \\
\hline & Soruların sistematikliğ $i$ & 3 & 3 & 3 & 3 & 3 & 3 & 3 \\
\hline & Uygulanabilirliği & 3 & 3 & 3 & 3 & 3 & 3 & 3 \\
\hline & Yöntemin adımlarına uygunluğu & 3 & 3 & 3 & 3 & 3 & 3 & 3 \\
\hline \multirow{5}{*}{$\begin{array}{l}\text { 6. Sinıf } \\
\text { Sesin İletimi }\end{array}$} & Kazanımlarla ilişki düzeyi & 3 & 2 & 2 & 3 & 3 & 3 & 2 \\
\hline & Kapsam yeterliliği & 3 & 3 & 3 & 3 & 3 & 3 & 3 \\
\hline & Soruların sistematikliği & 3 & 3 & 3 & 3 & 3 & 3 & 3 \\
\hline & Uygulanabilirliği & 3 & 3 & 3 & 3 & 3 & 3 & 3 \\
\hline & Yöntemin adımlarına uygunluğu & 3 & 3 & 3 & 3 & 3 & 3 & 3 \\
\hline \multirow{5}{*}{$\begin{array}{c}\text { 7. Sınıf } \\
\text { Maddenin Tanecikli Yapısı }\end{array}$} & Kazanımlarla ilişki düzeyi & 3 & 3 & 3 & 3 & 3 & 3 & 3 \\
\hline & Kapsam yeterliliği & 2 & 2 & 2 & 3 & 3 & 3 & 2 \\
\hline & Soruların sistematikliği & 3 & 3 & 3 & 3 & 3 & 3 & 3 \\
\hline & Uygulanabilirliği & 3 & 3 & 3 & 3 & 3 & 3 & 3 \\
\hline & Yöntemin adımlarına uygunluğu & 3 & 3 & 3 & 3 & 3 & 3 & 3 \\
\hline \multirow{5}{*}{$\begin{array}{l}\text { 8. Sinıf } \\
\text { Asitler ve Bazlar }\end{array}$} & Kazanımlarla ilişki düzeyi & 3 & 3 & 3 & 3 & 3 & 3 & 3 \\
\hline & Kapsam yeterliliği & 3 & 3 & 3 & 3 & 3 & 3 & 3 \\
\hline & Soruların sistematikliği & 3 & 3 & 3 & 3 & 3 & 3 & 3 \\
\hline & Uygulanabilirliği & 3 & 3 & 3 & 3 & 3 & 3 & 3 \\
\hline & Yöntemin adımlarına uygunluğu & 3 & 3 & 3 & 3 & 3 & 3 & 3 \\
\hline
\end{tabular}

Fen bilimleri öğretmenleri etkinliklerin dördü içinde kazanımlarla ilişki, kapsam yeterliliğinin yüksek, soruların sistematik ve aşamalı olduğu, etkinliklerin sınıflarda uygulanabilir olduğu ve sokratik sorgulama yönteminin adımlarına uygun olduğunu ifade etmiştir. Öğretmenlerden bazıları 7. sınıf maddenin tanecikli yapısı (atom, molekül, element, bileşik ve karışım) konusunun çok soyut olması ve kavramların çok fazla karıştııılması nedeniyle kavramları somutlaştırmak amacıyla oyun hamurlarıyla modellerin oluşturulması veya simülasyon gibi teknolojik araçlarla desteklenerek kullanılmasını önermiştir. Ayrıca öğretmenler bazı ifadelerin düzeltilmesine yönelik önerilerde bulunmuştur. Öğretmenlerin önerileri doğrultusunda etkinliklerde düzeltmeler yapılmıştır. Bu görüşlere dayalı olarak etkinliklerin yönteme oldukça uygun ve sınıflarda rahatlıkla uygulanabilir olduğu söylenebilir.

\section{Tartışma, Sonuç ve Öneriler}

Sokratik sorgulama yöntemine dayalı olarak geliştirilen fen etkinliklerinin uygulanabilirliğine yönelik öğretmen görüşlerinin incelenmesini amaçlayan bu çalışmada öğretmenlerin yöntem hakkında kısmen bilgilerinin olduğu ve derslerinde kısmen uyguladıkları, yöntemin fen bilimleri konuları için uygulanabilir bir yöntem olduğu, öğrencilerin öğrenme çıktıları üzerine olumlu etkilerinin olacağı, öğretmen yeterlilikleri ve öğrenci özelliklerinden kaynaklanan bazı güçlüklerin yaşanabileceğine yönelik görüşlere ulaşılmıştır. Öğretmenler tarafından soru cevap veya buldurmaya çalışma gibi yöntemin bazı bölümlerini derslerinde uygulanıyor olmasına karşılık bilmediğini 
hissettirme, sistematik soruların kullanılmaması, yöntemin uygulanabilir olduğunu ve öğretmenlerin yöntem hakkında bilgilendirilmesi gerektiğini ortaya koymaktadır. Al-Darwish (2012) yeni mezun öğretmenlerin öğrencilerini sorgulamaya teşvik ederken on yıllık deneyime sahip öğretmenlerin sadece sorduğu sorulara cevap beklemesi bulgusu öğretmenlerin yöntem hakkında bilgilendirilmesi gerektiğini desteklemektedir. Ancak yöntem ile ilgili olarak çok sınırlı sayıda çalışmanın yapılmış olması öğretime olumlu katkılar sağlayacak olan yönteme yeteri önem verilmediğini göstermektedir.

Öğretmenlerin hem yöntemin hem de fen bilimleri derslerinin günlük yaşamla ilişkili olması, yine fen bilimleri öğretim programı ve yöntemin sorgulama temelli, bilgiyi öğrenciye keşfettirme amaçlı olması ifadeleri, ayrıca yöntemin öğretmenler tarafından kısmen kullanılıyor olması sokratik sorgulama yönteminin oldukça uygulanabilir bir yöntem olduğunu göstermiştir. Ancak soyut olan kavram veya formüllerin verilmesi gereken konularda uygulayabilmek için yöntemin video, basit deney, anlam çözümleme tablosu, örnek olay gibi kavram öğretim araçları ile desteklenmesi gerekmektedir. Bu gereksinim önceki çalışma bulguları ile de uyumludur (Knezic vd., 2010; Lam, 2011). Ertuğrul ve İnan (2009) Bloom taksonomisine göre sokratik sorgulama yöntemini değerlendirdiği çalışmasında yöntemin çözümleme, değerlendirme ve yaratma basamaklarına uygun olduğu bulgusu yöntemin fen bilimleri dersinde uygulanabilir olduğunu desteklemektedir. Öğrencilerin kavram yanılgılarının ve kavram kargaşasının fazla, temel sorgulama becerilerinin düşük ancak günlük yaşam olaylarıyla çok fazla ilişkili olduğu fen bilimleri dersinde hem kavram yanılgılarını giderecek hem de öğrencilerin iletişim, eleştirel düşünme gibi üst düzey düşünme becerilerini ve sorgulama yeteneklerini arttıracak sokratik sorgulama yönteminin fen derslerinde kullanılması faydalı olacaktır (Emir, Hüner ve Üzelli, 2012; Lam, 2011; Şişman, 2009; Turnbull ve Mullins, 2007). Ancak 5. sınıflarda veya heterojen olan sınıflarda uygulandığında güçlükler yaşanabilir.

Öğretmenlerin sokratik sorgulama yöntemi fen derslerinde uygulandığında öğrencilerin başarı kalıcılık, motivasyon, üst düzey düşünme iletişim becerisi ve aktif katılımlarını arttıracağı yönündeki ifadeleri önceki çalışma bulgularıyla da uyumludur (Aydın, 2001; Emir ve diğ., 2012; Korkmazer, 2016; Şişman, 2009, Yıldız ve Dadi, 2019; Zeybek, 2019). Öğretmenlerin ifadeleriyle bu durumun muhtemel nedenleri öğrencinin hayatında olan kavram ve olaylarla derse başlanması, öğrencinin konu ya da kavramı bilmediğinin öğrenciye hissettirilmesi, öğrencinin bilgiyi kendisinin bulması ve son olarak ulaşılan bilgilerin gerek öğretmen gerekse öğrenci tarafından özetlenmesidir. Buradan yöntemin tüm aşamalarının öğrencilerin öğrenme çıktılarına etki ettiği görülmektedir. Ayrıca öğrenciler yöntemin aşamalarından birinin zaten bilmediğinin ortaya çıkarılması olduğunu bildiğinden yanlış yapmaktan çekinmeyecek ve derse katılacaktır. Yine öğretmenin sorularına cevap bulmak için hem kendi cevaplarını hem de arkadaşlarının cevaplarını çok boyutlu düşünmesi öğrencilerimizin eksik olduğu üst düzey düşünme becerilerini geliştirmesi bakımından önemlidir. Epçaçan (2013) çalışmasında yöntemin öğrencilerin okuduğunu anlama becerisini arttırdığı bulgusu bu önemi desteklemektedir. Öğrencilerin sınavlarda sürekli olarak test soruları (çoktan seçmeli) ile karşılaşmaları onların kendilerini ifade etmelerinde problemler yaşamalarına neden olmaktadır. Bu yöntemde öğrencilerin sürekli diyaloglara katılması, kendi düşüncelerini öğretmenin veya arkadaşlarının anlayabileceği şekilde ifade etmeye çalışmalarından dolayı kendilerini ifade etmede yaşadıkları problemlerin giderilmesinde faydalı olacağı söylenebilir.

Öğretmenler sokratik sorgulama yönteminin fen dersleri için oldukça uygun ve uygulanabilir bir yöntem ve öğrencilerin öğrenme çıktıları üzerine önemli katkıları olduğu görüşlerinin yanında yöntemin uygulanışı esnasında öğretmenlerin dikkat etmesi gereken hususlar olduğunu da ifade etmiştir. Öğretmenlerin dikkat etmesi gereken hususların başında öğrencilerden gelebilecek cevaplar ve öğretmen yeterliliği yer almaktadır. Sürekli aynı öğrencilerden cevap gelmesi, derse katılmayan öğrencilerin kendilerini geri planda tutması, öğrencilerden beklenenin dışında cevap gelmesi, konu dağıtacak nitelikte cevapların gelmesi, tüm öğrencilerin aynı anda cevap vermeye çalışması gibi öğrenci cevaplarından kaynaklanan sınıf yönetimini bozan, karmaşa ve gürültüye neden olabilecek 
güçlükler yaşanabilir. Yine öğretmenin deneyimsiz olması, iyi ve sistematik soru hazırlığının olmaması, pedagoji ve konu alan bilgisi eksikleri yönteminde uygulanması esnasında güçlüklerin yaşanmasına neden olabilir. Bu güçlüklerin yöntemin öneminden bahseden çalışmalarda da ortaya konulması bu hususlara dikkat edilmesi gerektiğine dikkat çekmektedir (Aydın, 2001; Delić ve Bećirović, 2016; Driver vd., 1998; Knezic vd., 2010; Korkmazer, 2016; Yıldız ve Dadi, 2019; Zeybek, 2019).

Sokratik sorgulama yönteminin kavram öğretiminde oldukça etkili olması nedeniyle 5E, probleme dayalı öğrenme gibi yenilikçi öğrenme yaklaşımlarının giriş veya keşfetme gibi adımlarında bir teknik olarak kullanılabileceği gibi zenginleştirilmiş etkinlikle tek başına bir yöntem olarak da rahatlıkla uygulanabilir. Bazı öğretmenler sokratik sorgulama yöntemini $5 \mathrm{E}$, probleme dayalı gibi yenilikçi yöntemlerden daha kolay uygulanabilir olduğunu ifade etmiştir. Soru cevap, buldurma gibi etkinliklerle kısmen uyguladıklarını ifade etmeleri de bunu desteklemektedir. Sokratik sorgulama yönteminin başlama, bilmediğini hissettirme ve buldurma adımları $5 \mathrm{E}$ yönteminin giriş ve keşfetme hatta derinleştirme, probleme dayalı yöntemin problemin fark edilmesi adımlarıyla benzerlik göstermesinden dolayı yenilikçi yöntemlerin bu adımlarının etkisini arttırmak adına hibrit kullanımların faydalı olacağı düşünülebilir.

Bu çalışmada elde edilen bulgular ve yapılan tartışmalar dikkate alındığında hem sokratik sorgulama yönteminin sahip olduğu özellikler hem de fen bilimleri dersinin özelliklerinin birbirine uyumlu olması nedeniyle kavram yanılgısı ve kavram kargaşasının oldukça fazla olduğu fen bilimleri dersinde yöntemin ve etkinliklerin uygulanabilir olduğu sonucuna varılmıştır. Bununla birlikte fen bilimleri dersinin soyut olan veya kavram öğretiminin olduğu bazı konularında ise çeşitli etkinliklerle zenginleştirilerek uygulanabileceği sonucuna ulaşılışstır. Yöntem fen derslerinde uygulandığında öğrencilerin öğrenme çıtıları üzerine olumlu etkilerinin olacağııın yanında öğrenci özellikleri ve öğretmen yeterliliklerinden kaynaklanan bazı güçlüklerle karşılaşılabileceği anlaşılmıştır. Ayrıca öğretmenlerin yöntemi soru cevap yöntemi olarak algıladıkları, soru cevap ve buldurma gibi yöntemin bazı adımlarını derslerinde kullanmaya çalıştıkları sonucuna ulaşılmışır. Ayrıca ulusal literatürde fen eğitiminde yapılan iki üç çalışma dışında fazla çalışmanın olmaması yönteme gerekli önemin verilmediğini ortaya koymuştur. Bu çalışmada ortaya çıkan bu sonuçlar temelinde yöntemi derslerinde uygulayacak öğretmenlere ve yöntemle ilgili akademik çalışma yapacak olan araştırmacılara aşağıdaki öneriler sunulmaktadır.

\section{Öğretmenlere yönelik öneriler}

$\checkmark$ Sokratik sorgulama yönteminin fen derslerinde uygulanabilir bir yöntem olması ve öğretmenlerin bu yöntemi soru cevap yöntemiyle karıştırmalarından dolayı öğretmenlere bu yöntemin tanıtılığı hizmet içi eğitimler verilebilir. Öğretmen adaylarının bilgilendirilmesi amacıyla ise öğretim elemanları öğretim derslerinde bu yönteme yer verebilirler.

$\checkmark$ Öğretmen yeterliliğinin yöntemin uygulanması esnasında güçlüklerin yaşanmasına neden olacağından dolayı bu yöntemi derslerinde kullanacak olan öğretmenler sokratik sorgulama yöntemini derslerinde kullanmadan önce mutlaka iyi hazırlanmış sistematik soruları belirlemeli ve öğrencilerden gelebilecek muhtemel cevaplara da hazırlıklı olmalıdır.

$\checkmark$ Öğrenci özelliklerinin yöntemin uygulanması esnasında güçlüklerin yaşanmasına neden olacağından dolayı yöntemi derslerinde uygulayacak olan öğretmenler kendi hazırlayacağı sorularda tüm sınıfı derse katabilecek, öğrenci katılımının sürekliğini sağlayacak özelliklerin olmasına ve öğrencilerden gelebilecek beklenmedik cevaplara karşı konuyu toparlayıcı yeni sorular sormaya, cevapları farklı öğrencilerden almaya, böylece iyi bir sınıf yönetimi sağlama konusuna dikkat etmelidir. Ayrıca öğretmen yöntemi öğrencileri sıkmadan ve çok fazla zaman harcamadan uygulamalıdır. 
Fen bilimleri öğretmenleri derslerinde kullandıkları soru cevap veya buldurma yöntemini bilmediğini hissettirme ve buldurma adımları üzerine vurgu yaparak soru cevap veya tartışma sorularını sistematik hale getirerek, etkinliklerle zenginleştirip yöntemlerini sokratik sorgulama yöntemine dönüştürebilirler.

$\checkmark$ Fen bilimleri öğretmenleri sokratik sorgulama yöntemini kavram yanılgılarını gidermede etkili olduğundan dolayı öğrencilerin kavram yanılgılarını ve kavram kargaşalarını gidermek amacıyla derslerinde kullanabilirler.

$\checkmark$ Sadece soru cevap diyaloglarının kullanılması belli bir süre sonra öğrencileri sıkacağından dolayı öğretmenler sokratik sorgulama yöntemini kullanırken basit deneyler, küçük etkinlikler, örnek olaylar, anlam çözümleme tabloları, yapılandırılmış grid gibi kavram öğretimi araçlarıyla yöntemi zenginleştirmelidir.

$\checkmark$ Ön öğrenmeler yöntemin uygulanabilirliğini arttırdığından dolayı öğrenilen kavram sayısı arttıkça yöntemin uygulanması daha kolay olacaktır. Bu nedenle yöntem ilk uygulandığında öğretmen ihtiyaç duyduğu bazı bölümlerde müdahalede bulunup açıklama yapabilir.

$\checkmark$ Alt sınıflarda ve heterojen sınıflarda uygulanması esnasında güçlükler yaşanabileceğinden dolayı bu tür sınıflarda öğretim yapacak olan öğretmenler daha fazla hazırlanmalı ve öğrencilerden gelebilecek sorulara daha fazla hazırlıklı olmalıdır.

\section{Araştırmacılara yönelik öneriler}

$\checkmark$ Sokratik sorgulama yöntemi çok az çalışılan bir konu olduğundan araştırmacılar çeşitli fen konularına yönelik sokratik sorgulama etkinlikleri geliştirerek bu etkinliklerin öğrenme çıktıları üzerine etkisini inceleyen deneysel çalışmalar yapılabilirler.

$\checkmark$ Bu çalışmada öğretmenlerin yöntemi broşür ve hazırlanan etkinliklerle değerlendirmeleri sınırlılığını aşmak için sonraki çalışmalarda uygulamalı ve deneysel çalışmalar yapılabilir.

$\checkmark$ Araştırmacılar geliştirdikleri etkinlikleri gerçek sınıf ortamında uyguladıktan sonra yöntem hakkında öğrenci görüşlerini ortaya koyacak çalışmalar yapabilirler.

$\checkmark$ Sokratik sorgulama yöntemi ve diğer yenilikçi yöntemleri hibrit olarak kullanılmasının kavram öğretimine ve öğrenme çıktıları üzerine etkisi ile ilgili çalışmalar yapılabilir.

$\checkmark$ Öğretmenler tarafından derse katılmayan ve heterojen sınıflarda uygulanmasının güçlük oluşturacağı düşünüldüğünden bu tür sınıflarda uygulamaların öğrencilerin derse katılmalarına olan etkisi incelenebilir.

$\checkmark$ Farklı seviyedeki öğretim kademelerinde yöntemin etkisi incelenebilir. 


\section{Kaynakça}

Aktas, i. ve Bilgin, i. (2015). The effect of the 4MAT learning model on the achievement and motivation of 7th grade students on the subject of particulate nature of matter and an examination of student opinions on the model. Research in Science and Technological Education, 33(1), 1-21. doi: $10.1080 / 02635143.2014 .968536$

Aktaş, ì. ve Özmen, H. (2020). Investigating the impact of TPACK development course on pre-service science teachers' performances. Asia Pacific Education Review, 21, 667-682. doi: 10.1007/s12564-020-09653-x

Al-Darwish, S. (2012). The role of teacher questions and the socratic method in efl classrooms in kuwait. World Journal of Education, 4(2), 76-84. doi: 10.5430/wje.v2n4p76

Aydın, M. Z. (2001). Aktif öğretim yöntemlerinden buldurma (Sokrates) yöntemi. Cumhuriyet Üniversitesi ilahiyat Fakültesi Dergisi, 5(1), 55-80.

Aydoğan, S., Güneş, B. ve Gülçiçek, Ç. (2003). Isı ve sıcaklık konusunda kavram yanılgıları. Gazi Eğitim Fakültesi Dergisi, 23(2), 111-124.

Ayvacı, H. Ş. ve Bakırcı, H. (2018). Farklı öğretim kademelerindeki öğrencilerin ses konusundaki kavramsal gelişimlerinin incelenmesi. Journal of Instructional Technologies and Teacher Education, 7(1), 1-17.

Benlikaya, R. (2018). Atom, molekül ve maddenin tanecikli yapısı. G. Dolu (Ed.), Kimyada kavram yanılgıları (s. 19-32) içinde. Ankara: Pegem Akademi.

Bilgin, İ., Aktaş, ì. ve Çetin, A. (2014). Öğrenci takımları başarı bölümleri tekniğinin ilköğretim öğrencilerinin zihinsel yapılarına etkisi. Ilköğretim Online, 13(4), 1531-1551. doi: 10.17051/io.2014.29266

Bostan-Sarığlan, A. (2016). Conceptual level of understanding about sound concept: Sample of fifth grade students. E-International Journal of Educational Research, 7(1), 87-97. doi: 10.19160/e-ijer.49269

Bozer, E. N. (2014). Ortaöğretim 9-12. Sınıf öğrencilerinde Sokratik sorgulama beceri ölçeği geliştirilmesi çalışması. (Yayımlanmamış yüksek lisans tezi). Necmettin Erbakan Üniversitesi, Eğitim Bilimleri Enstitüsü, Konya.

Chang, K., Lin, M. ve Chen, S. (1998). Application of the Socratic dialogue on corrective learning of subtraction. Computers and Education, 31, 55-68. doi: 10.1016/S0360-1315(98)00017-7

Chorzempa, B. F. ve Lapidus, L. (2009). Using socratic discussions in Inclusive classrooms. Teaching Exaptional Children, 41(3), 54-59.

Coştu, B., Ayas, A. ve Ünal, S. (2007). Kavram yanılgıları ve olası nedenleri: Kaynama kavramı. Kastamonu Eğitim Dergisi, 15(1), 123-136

Creswell, J. W. (2014). Research design: Qualitative, quantitative and mixed methods approaches (4. bs.). Thousand Oaks, CA: Sage.

Çebi, B. (2006). Sokratesçi öğretme yaklaşımının ilköğretim Türkçe eğitim programına yansıması ve uygulamadaki durum. (Yayımlanmamış yüksek lisans tezi). Ondokuz Mayıs Üniversitesi, Sosyal Bilimler Enstitüsü, Samsun.

Çelikler, D. ve Kaya, F. (2016). Ortaokul 5. sınıf öğrencilerinin “maddenin değişimi” ünitesindeki bilgilerini günlük yaşamla ilişkilendirebilme düzeyleri açısından hazırbulunuşluklarının belirlenmesi. Kafkas Üniversitesi Sosyal Bilimler Enstitüsü Dergisi, 17, 21-39.

Çoban, O. (2016). Sokratik sorgulama yöntemi ile sorumluluk değerinin öğretimi. (Yayımlanmamış Doktora Tezi). Uşak Üniversitesi, Sosyal Bilimler Enstitüsü, Uşak.

Delić, H. ve Bećirović, S. (2016). Socratic method as an approach to teaching. European Researcher. Series $A$, 111(10), 511-517. doi: 10.13187/er.2016.111.511

Dolu, G. (2018). Elementler, bileşikler ve karışımlar. G. Dolu (Ed.), Kimyada kavram yanılgıları (s. 33-42) içinde. Ankara: Pegem Akademi.

Driver, R., Guesne, E. ve Tibergihen A. (1998). Childrens' ideas in science. Milton Keynes: Open University Press.

Ecevit, T. ve Özdemir-Şimşek, P. (2017). Öğretmenlerin fen kavram öğretimleri, kavram yanılgılarını saptama ve giderme çalışmalarının değerlendirilmesi. ilköğretim Online, 16(1), 129-150. doi: 10.17051/io.2017.47449

Emir, S., Hüner, S. B. ve Üzelli, O. (2012, Eylül). Sokratik sorgulama yönteminin akademik başarı, eleştirel düşünme ve üstbilişsel farkındalık düzeyleri üzerindeki etkisinin incelenmesi. 2. Ulusal Eğitim Programları ve Öğretim Kongresinde sunulan bildiri, Abant İzzet Baysal Üniversitesi Eğitim Fakültesi, Bolu.

Epçaçan, C. (2013). Sokrat Semineri tekniğine dayalı öğretimin öğrencilerin okuduğunu anlama becerisine ve okumaya ilişkin tutuma etkisi. Akademik Araştırmalar Dergisi, 58, 93-116. 
Ertuğrul, i. ve İnan, B. (2009). Socratic method: Its role in the cognitive domain of Bloom's taxonomy and its use in advanced elt literature classes to teach plato's republic. Dumlupınar Üniversitesi Sosyal Bilimler Dergisi, 25(3), 119-125.

Fraenkel, J.R., Wallen, N.E. ve Hyun, H.H. (2012). How to design and evaluate research in education (8. bs.). New York: McGraw Hill Higher Education.

Gökulu, A. (2015). Sınıf öğretmeni adaylarının “ıSı, sıcaklık, hal değişimi” kavramlarını anlama seviyelerine ilişkin bir çalışma. Mersin Üniversitesi Eğitim Fakültesi Dergisi, 11(2), 300-314. doi: 10.17860/efd.56083

Johnson, R. B. ve Christensen, L. B. (2004). Educational research: Quantitative, qualitative, and mixed approaches. Boston, MA: Allyn and Bacon.

Kırbulut, Z. D. ve Beeth, M. E. (2013). Representations of fundamental chemistry concepts in relate to the particulate nature of matter. International Journal of Education in Mathematics, Science and Tehnology, 1(2), 96-106.

Kırıkkaya, E. B. ve Güllü, D. (2008). İlköğretim 5. sınıf öğrencilerinin ıSı-sıcaklık ve buharlaşma-kaynama konularındaki kavram yanılgıları. Ilköğretim Online, 7(1), 15-27.

Knezic, D., Wubbels, T., Elbers, E. ve Hajer, M. (2010). The Socratic Dialogue and teacher education. Teaching and Teacher Education, 26, 1104-1111. doi: 10.1016/j.tate.2009.11.006

Koray, Ö. ve Tatar, N. (2003). Illköğretim öğrencilerinin kütle ve ağırlık ile ilgili kavram yanılgıları ve bu yanılgıların 6., 7. ve 8. sınıf düzeylerine göre dağılımı. Pamukkale Üniversitesi Eğitim Fakültesi Dergisi, 1(13), 187-198.

Korkmazer, A. (2016). Sokrates yöntemi kullanılarak maddenin hal değiştirmesi konusunun öğretilmesi. (Yayımlanmamış Yüksek Lisans Tezi). İnönü Üniversitesi, Eğitim Bilimleri Enstitüsü, Malatya.

Lam, F. (2011). The Socratic Method as an Approach to Learning and Its Benefits. Carnegie Mellon University. Thesis. doi. 10.1184/R1/6686570.v1

Longo, K. J. (2007). Using a Socratic Dialogue to teach the mole concept to adult learners. Journal of Chemical Education, 84(8), 1285-1286. doi: 10.1021/ed084p1285

Miles, M. B. ve Huberman, A. M. (1994). Qualitative data analysis: An expanded sourcebook (2. bs.). Thousand Oaks, CA: Sage.

Milli Eğitim Bakanlığı [MEB] (2013). Ilköğretim kurumları fen bilimleri dersi (3.-8. sınıflar) öğretim programı. Ankara: Devlet Kitapları Müdürlüğü Basımevi.

Milli Eğitim Bakanlığı [MEB] (2018). Ilköğretim kurumları fen bilimleri dersi (3.-8. sınıflar) öğretim programı. Ankara: Devlet Kitapları Müdürlüğü Basımevi.

Özmen, H. (2011). Turkish primary students' conceptions about the particulate nature of matter. International Journal of Environmental and Science Education, 6(1), 99-121.

Özmen, H. ve Karamustafaoğlu, O. (Ed.). (2019). Eğitimde araştırma yöntemleri. Ankara: Pegem Akademi.

Pabuçcu, A. ve Geban, Ö. (2015). 5E öğrenme döngüsüne göre düzenlenmiş uygulamaların asit-baz konusundaki kavram yanılgılarına etkisi. Abant İzet Baysal Üniversitesi Eğitim Fakültesi Dergisi, 15(1), 191-206.

Pihlgren, A. S. (2008). Socrates in the classroom: Rationales and effects of philosophizing with children. (Yayımlanmamış Doktora Tezi). Stockholm University.

Sarı-Ay, Ö. ve Aydoğdu, C. (2015). Maddenin halleri ve ısı konusunda kavram yanılgılarının giderilmesinde kavramsal değişim metinlerinin etkisi. Hacettepe Üniversitesi Eğitim Fakültesi Dergisi, 30(2), 99-111.

Sönmez, V. (2005). Eğitim felsefesi. Ankara: Anı Yayıncılık.

Şişman, S. (2009, Ekim). Sokratik yöntem kullanılarak yapılan din kültürü ve ahlak bilgisi derslerinin, öğrencilerin eleştirel düşünme eğilimleri ve derse karşı tutumları üzerindeki etkileri. XVIII. Ulusal Eğitim Bilimleri Kurultayında sunulan bildiri, Ege Üniversitesi Eğitim Fakültesi, İzmir.

Turnbull, W. ve Mullins, P. (2007). Socratic Dialogue as personal reflection. Reflective Practice, 8(1), 93-108. doi: $10.1080 / 14623940601139012$

Yıldırım, A. ve Şimşek, H. (2011). Sosyal bilimlerde nitel araştırma yöntemleri. Ankara: Seçkin.

Yıldız, A. ve Dadi, M. (2019). Buldurma (Sokrates) yönteminin kullanılarak “Avagadro sayısı”nın öğretilmesi. Iğdır Üniversitesi Sosyal Bilimler Dergisi, 17, 369-402.

Yılmazlar, M., Takunyacı, M. ve Günaydın, G. (2014). Öğretim programı değişikliği ile birlikte 6. sınıf öğrencilerinin kuvvet ve hareket konusundaki kavram yanılgıları. International Journal of Social Science, 24, 161-81. doi: 10.9761/JASSS2288

Yin, R. K. (2009). Case study research: Design and methods (4. bs.). Thousand Oaks, CA: Sage.

Zeybek, G. (2019). Sokratik sorgulama yöntemi ile "Ohm kanunu” konusunun öğretimi. Eğitim Kuram ve Uygulama Araştırmaları Dergisi, 5(1), 53-63. 


\section{EK 1. YARI YAPILANDIRILMIŞ GÖRÜŞME SORULARI}

1. Sokrates yöntemi hakkında daha önce bir bilginiz var mıydı?

2. Sokrates yönteminin, fen konularına yönelik uygulanabilir bir yöntem olduğunu düşünüyor musunuz?

3. Sokrates yöntemi fen bilimleri dersinin her konusu için uygulanabilir mi? Neden? Sokrates yöntemi ne tür konuların öğretimine uygundur?

4. Sokrates yöntemine göre bir fen konusu sunulduğunda öğrencilerin öğrenme çıktılarına (akademik başarı, kalıcılık, motivasyon gibi çıktılar) etkisi ne olur?

5. Sokrates yöntemini fen bilimleri dersinde kullanıldığında ne gibi zorluklarla karşılaşıır?

6. İncelediğiniz etkinliklerde Sokrates yönteminin olumsuz yönlerini gördünüz mü? Varsa nelerdir?

7. 5. sınıf maddenin hal değişimi konusuna yönelik hazırlanan etkinliklerin içeriğini ve uygulanışını nasıl buldunuz?

8. 6. sınıf sesin madde ile etkileşimi konusuna yönelik hazırlanan etkinliklerin içeriğini ve uygulanışını nasıl buldunuz?

9. 7. sınıf element-bileşik-molekül konusuna yönelik hazırlanan etkinliklerin içeriğini ve uygulanışını nasıl buldunuz?

10. 8. sınıf asitler ve bazlar konusuna yönelik hazırlanan etkinliklerin içeriğini ve uygulanışını nasıl buldunuz?

11. Sokrates yönteminin uygulanmasına ilişkin genel değerlendirmeniz nelerdir? 


\section{EK 2. ETKINLIIKLER}

ETKİNLİK 1: Maddenin Hâl Değişimi

SINIF: 5. Sinif

Önerilen Süre: 2 ders saati

Konu/kavramlar: erime, donma, kaynama, yoğunlaşma, buharlaşma, süblimleşme, kırağılaşma.

Kazanımlar:

F.5.4.1.1. Maddelerin ısı etkisiyle hal değiştirebileceğine yönelik yaptığı deneylerden elde ettiği verilere dayalı çıkarımlarda bulunur.

F.5.4.1.2. Maddenin hal değiş̧iminin Isı alışverişi ile gerçekleştiğini bilir.

Sıvların her sıcaklıkta buharlaşstı̆̆ fakat belirli sıcaklıkta kaynadığı belirtilerek buharlaşma ve kaynama arasındaki temel fark açıklanır.

Öğretmen: Çocuklar daha önce öğrenmiştik doğada maddeler kaç halde bulunuyordu? Bir hatırlayalım. Ön bilgilerle derse başlama

Öğrenci: Kat1, sıv1 ve gaz halinde bulunur.

Öğretmen: Katı halde bulunan maddelere örnek verebilir misiniz?

Öğrenci: Tahta, demir, cam, kalem, buz...

Öğretmen: Sıvı halde bulunan maddelere örnek verebilir misiniz?

Öğrenci: Su, yağ, süt...

Öğretmen: Peki, gaz halde bulunan maddelere örnek verebilir misiniz?

Öğrenci: Hava, oksijen, tüp, buhar...

Öğretmen: Şimdi size başımdan geçen bir olayı anlatacağım.

Örnek Olay: Çocuklar okuldan sonra eve gittiğimde iki gün önce buz kalıplarının içine atıp buzdolabına koyduğum suyun donduğunu gördüm. Bende soğuk meyve suyu içmek için birkaç tane buz parçası alıp meyve suyunun içine attım. Sonra meyve suyunu içmeye başladım ama meyve suyum bitmeden buzların kaybolduğunu gördüm. Buz parçalarına ne oldu, niye kayboldular?

Öğrenci: Buzlar eridi.

Öğretmen: Erime nedir?

Öğrenci: Buzdolabından çıkardığımız buz biraz bekledikten sonra suya dönüşür. İlkbaharda karlar erir. Tereyağını tavada 1 sıttığımızda erir. Bunlar erimedir.
Öğretmen: Buradan erimenin genel tanımını yapabilir misiniz?

Öğrenci: Maddenin katıdan sıvıya geçmesidir.

Öğretmen: Peki maddenin sıvıdan gaz hale geçişine örnek verecek olan var mı?

Öğrenci: Suyu kaynattı̆̆ımızda buhar olur. İlkbaharda karlar eriyip buharlaşır yerler kurur.

Öğretmen: Çok güzel! Peki, bu dönüşümlerin tersi olur mu?

Öğrenci: Evet olabilir. ...

Öğretmen: Peki bir katı nasıl erir?

Öğrenci: Isıttığımızda

Öğretmen: Evet. Şimdi size bir örnek vermek istiyorum. İki tane çocuk düşünün. Bir çocuk odasında sakin sakin oturuyor, oyuncaklarıyla oynuyor. Diğer çocuk kanepelerin üzerinde hoplayıp zıplıyor, odanın bir o tarafına bir diğer tarafına koşturuyor. Hangisinin enerjisi daha fazladır? Analojilerden faydalanma

Öğrenci: Zıplayan çocuğun...

Öğretmen: Peki buz, su ve buhar örneğinden yola çıkarak katı, sıvı ve gazları çocuklara benzetirsek hangisinin enerjisi daha fazladır? Katıların mı, siviların mı, gazların mı?

Öğrenci: Buhar uçtuğundan daha hareketlidir. O zaman gazların enerjisi daha fazladır.

Öğretmen: En az olan hangisidir?

Öğrenci: Buz, yani katıların. 
Öğretmen: Peki az olandan fazla olana doğru bir siralama yaparsanız nasil bir siralama olur?

Öğrenci: Katı, sıvı, gaz

Öğretmen: Şimdi az önce konuştuklarımızı düşünün. Buz, su haline geçince enerjisi nasıl değişir? Artar mı, azalır mı?

Öğrenci: Artar.

Öğretmen: Peki bu enerjiyi nerden alıyor? Nasıl oluyor da enerjisi artiyor?

Öğrenci: Isınarak olabilir...

Öğretmen: $O$ halde 1 sı enerjidir. Madde katı halden sıvı hale geçerken 1sı alır diyebilir miyiz? Ulaşılan bilgiyi özetleme

Peki, buradan hal değişimleriyle ilgili bir genellemeye gidebilir miyiz?

Öğrenci: Maddeler katı halden sıvı hale geçerken veya sıvı halden gaz haline geçerken 1sı alırlar.

Öğretmen: Çok güzel! Peki, bu hal değişimlerinin tersi için ne söyleyebiliriz?

Öğrenci: O zaman gaz halinden sıvı hale geçerken veya sıvı halden gaz haline geçerken bu defa isı verir.

Öğretmen: Peki, sizce katı haldeki bir madde 1S1 alarak sıvı hale geçmeden gaz hale geçebilir mi? Bilmediğini fark ettirme

Öğrenci: Hımm. Bilmiyorum.

Öğretmen: Sonbahar aylarında sabah uyandığınızca bahçede ağaçların veya çimenlerin üzerinde hiç beyazlaşma gördünüz mü?

Öğrenci: Evet

Öğretmen: Bitkilerin beyazlaşmasına ne diyoruz? Anne babanızdan duydunuz mu?

Öğrenci: Kırağı̆laşma.

Öğretmen: Evet peki bu kırağılaşma nasıl oluyor hiç düşündünüz mü?

Öğrenci: Gece kar yağıyor.

Öğretmen: Hayır

Öğrenci: Bitkiler terliyor.

Öğretmen: Gece o kadar soğukta terleme olur mu?

Öğrenci: Hayır.

Öğretmen: Hal değişimini düşünün biraz. Peki, katıdan gaza ya da gazdan katıya bir hal değişimi olamaz mı?

Öğrenci: Bilmiyorum. Olabilir.
Öğretmen: Bitkilerin üzerindeki beyazlıklar katı buz parçaları yani kar değil midir?

Öğrenci: Evet.

Öğretmen: Kırăğlaşma sıvıdan katıya olsaydı donma denirdi değil mi?

Öğrenci: Evet.

Öğretmen: O halde geriye hangi ihtimal kalıyor.

Öğrenci: Gazdan katıya.

Öğretmen: Hal değişimiyle ilgili öğrendiğiniz bilgilerden kırağılaşmanın tanımını yapabilir misiniz?

Öğrenci: Bir maddenin gaz halinden (1S1 vererek) katı hale geçmesine kırağılaşma denir? Özetleme

Öğretmen: Aferin, çok güzel! Şimdi size yeni bir örnek vereyim. Derin dondurucunun kapağını açtı̆̆ınızda soğuk bir buhar çıktığına hiç şahit oldunuz mu?

Öğrenci: Evet.

Öğretmen: Normalde buhar sıcak olmaz mı?

Öğrenci: Evet. Sicak olur.

Öğretmen: Peki buzluktan çıkan buhar nasıl oluyor da soğuk oluyor?

Öğrenci: Bilmiyorum.

Öğretmen: Kırağılaşma gibi direk geçişle alakalı olabilir mi?

Öğrenci: Olabilir. O zaman katı halden direk gaz hale geçmeyle mi oluyor.

Öğretmen: Evet. Biz maddelerin katı halden gaz hale geçmesine süblimleşme diyoruz. Peki, süblimleşme 1sı alarak mı yoksa isı vererek mi gerçekleşir?

Öğrenci: Gaz taneciklerinin enerjisi (1SIS1) daha yüksek olduğundan 1sı alarak gerçekleşir.

Öğretmen: Peki, naftalinin bir süre sonra kaybolmasını süblimleşmeye örnek olarak verebilir miyiz?

Öğrenci: Evet.

Öğretmen: Neden verebiliriz?

Öğrenci: Çünkü naftalin katı, sıvı hale geçmeden gaz haline geçerek ortadan yok oluyor.

Öğretmen: Şöyle özetleyebilir miyiz? Bir maddenin katı halden sıvı hale geçmesine erime olayı, sıvı halden gaz haline geçmesine buharlaşma olayı, katı halden gaz haline geçmesine ise süblimleşme denir. Ayrıca bu olayların hepsi isı alarak gerçekleşir. Özetleme 
Öğrenci: Evet.

Öğretmen: Peki. Bu hal değişimlerinin tersini nasıl özetleriz?

Öğrenci: Bir maddenin sıv1 halden katı hale geçmesinde donma olayı, gaz halden sıvı hale geçmesine yoğunlaşma olayı, gaz halden katı hale geçmesine ise kırağılaşma denir. Bu olaylar 1s1 vererek gerçekleşir. Özetleme

Öğretmen: Çok güzel! Maddelerin hal değişimlerinin adlarını, hangi hal değişimlerinde isı alındığını, hangi hal değişimlerinde $1 \mathrm{~S} 1$ verildiğini buldunuz.

Peki, su ne zaman sıvı halden gaz haline geçer?

Öğrenci: Kaynadığında.

Öğretmen: Peki buharlaşma neydi?

Öğrenci: Suyun gaz haline geçmesi.

Öğretmen: $O$ zaman kaynama ile buharlaşma arasındaki fark nedir? Aynı şey midir? Bilmediğini fark ettirme

Öğrenci: Hımm. Bilmiyorum.

Öğretmen: Çaydanlığa koyduğunuz suyun kaynadığını nasıl anlarsınız?

Öğrenci: Isınırken fokurdar, kabarcıklar çıkar ve sürekli buhar çıkar.

Öğretmen: Bu olaya ne diyoruz?

Öğrenci: Kaynama.

Öğretmen: $O$ zaman sıvıların gaz haline geçmesinin başka bir yolu da kaynamadır diyebilir miyiz?

Öğrenci: Evet.

Öğretmen: $\mathrm{Bu}$ durumda buharlaşmanın kaynamadan farkı nedir?

Öğrenci: Hımm. Bilmiyorum.

Öğretmen: Peki, ıslak çamaşırları bahçeye astığımızda ne oluyor da çamaşırlar kuruyor?

Öğrenci: Sular yere akıyor.

Öğretmen: O zaman örneği biraz değiştireyim. Bir bardağın dibine çok az su koyduğunuzda bir gün sonra suyun olmadığını, kaybolduğunu görürsünüz. $\mathrm{Bu}$ nasil oluyor?

Öğrenci: Gaz olup uçarak.

Öğretmen: Bu olaya ne deriz?

Öğrenci: Buharlaşma.
Öğretmen: Evet. Çamaşırlardaki su da buharlaşıp gidiyor. Çamaşırlar kururken havanın sıcaklığı kaç derece olur?

Öğrenci: Değişiyor. Yazın da kışında çamaşırlar dışarda kuruyor. Her sıcaklıkta olur.

Öğretmen: Peki, farklı yerlerde farklı sıcaklıklarda kuruma oluyorsa, buharlaşmanın meydana geldiği sıcaklık için ne deriz?

Öğrenci: Her sıcaklıklarda buharlaşma oluyor diyebiliriz.

Öğretmen: $O$ zaman buharlaşma her sıcaklıkta, kaynama ise belli bir sıcaklıkta olur diyebilir miyiz?

Öğrenci: Evet, diyebiliriz.

Öğretmen: Kaynamayı görmüşsünüzdür. Nasıl oluyordu yani ne gözlemleriz?

Öğrenci: Suyun her tarafı fokurdar ve alttan kabarcıklar hızla yukarı çıkar.

Öğretmen: Yani kaynama sıvının her tarafında, hızla ve belli bir sicaklıkta meydana gelir diyebiliriz. Peki, buharlaşma nasıl oluyor? Fokurdama oluyor mu? Özetleme

Öğrenci: Hayır. Suyun hemen üstünde buhar yukarı çıkar.

Öğretmen: $O$ zaman buharlaşma için de sıvının yüzeyinde, yavaşça ve her sıcaklıkta olur diyebilir miyiz? Özetleme

Öğrenci: Evet, diyebiliriz.

Öğretmen: böylece kaynama ve buharlaşma arasındaki farkı da bulmuş oldunuz.

Bu sorgulama diyaloğu ögrencilerden gelen cevaplar doğrultusunda oluşturulmuştur. Ancak sinıf, öğrenci gibi değişkenlere bağll olarak gelebilecek cevaplarda farklliklar olabilir. Uygulamayl yapacak ögretmen gerek farklı sorulara gerekse akış içerisinde ara sorulara cevap verecek şekilde kendilerini hazırlamalıdır. 
Önerilen Süre: 2 ders saati

Konu/Kavramlar: Sesin katı, sıvı ve gazlarda yayılması. Farklı cisimlerde üretilen seslerin farklılığı, aynı sesin farklı ortamlarda farklı duyulması

\section{Kazanımlar:}

F.6.5.1.1. Sesin yayılabildiği ortamları tahmin eder ve tahminlerini test eder.

F.6.5.2.1. Ses kaynağının değişmesiyle seslerin farklı işitildiğini deneyerek keşfeder.

F.6.5.2.2. Sesin yayıldığı ortamın değişmesiyle farklı işitildiğini deneyerek keşfeder.

Frekans kavramına girilmez.

Örnek Olay: Fen dersine gelen öğretmen okulun önünde çalışan iş makinalarından (ya da dışarda oynayan öğrencilerden) gelen seslerden rahatsız olduğu için sınıfın pençelerinin kapatılmasını söyledi. Ancak sesler hala sinıfta duyuluyordu. Pencereyi kapatmamıza rağmen hala sesleri duyuyoruz. Bu nasıl oluyor? diye öğrencilere soru sormaya başladi.

Öğretmen: Dişardan gelen sesleri duyuyor musunuz? Yaşantıdan derse başlama

Öğrenci: Evet duyuyoruz.

Öğretmen: Çevrenizde gün içinde başka hangi sesleri duyuyorsunuz?

Öğrenci: Arkadaşımızın seslerini. Anne babamızın kardeşlerimizin seslerini. Araçların seslerini. Kuşların seslerini...

Öğretmen: Peki çocuklar bu sesler nasıl oluşuyor?

Öğrenci: Himm. Bilmiyorum... sesin nasıl oluştuğunu bilmediğini fark ettirme.

Öğretmen: Eline aldığ cetvelin bir ucu masanın dışında kalacak şekilde masanın üstüne koyar. Masanın üstünde kalan ucuna bastırarak dışarda kalan ucunu yukarl kaldırarak serbest birakır. Cetvel titrer ve ses çıkarır.

Bir şey duyuyor musunuz? Basit deneylerle buldurmaya yönlendirme

Öğrenci: Evet ses geldi.

Öğretmen: Peki, duyduğunuz bu ses nasıl oluştu?

Öğrenci: Cetvelin titremesiyle...

Öğretmen: $\mathrm{O}$ zaman sesin maddelerin titreşimiyle oluştuğunu söyleyebilir miyiz? Özetleme.

Öğrenci: Evet
Öğretmen: Peki bu ses nasıl iletilir. Cetvelin sesi size nasıl ulaştı?

Öğrenci: Boşlukta geldi, duyduk.

Öğretmen: Sınıfın içi boşluk mu?

Öğrenci: Evet.

Öğretmen: Maddenin kaç hali vardı?

Öğrenci: 3 hali var. Katı, sıv1 ve gaz.

Öğretmen: Gazlara örnek verebilir misiniz?

Öğrenci: Oksijen, karbondioksit, buhar

Öğretmen: Biz nefes alırken ne yapıyoruz?

Öğrenci: Oksijen alıp, karbondioksit veriyoruz.

Öğretmen: Peki bu gazları nerden alıp nereye veriyoruz?

Öğrenci: Havadan alıp havaya veriyoruz.

Öğretmen: $O$ halde şimdi sınıf ortamında hangi gazlar var?

Öğrenci: Oksijen, karbondioksit.

Öğretmen: $\mathrm{Bu}$ durumda sınıfın boş olduğunu söyleyebilir miyiz?

Öğrenci: Hayır.

Öğretmen: Bu durumda sınıfın boşluk olmadığını sesinde boşlukta gelmediğini söyleyebiliriz. O zaman cetvelin sesi nasıl bize geldi sorusuna dönelim. Başka fikri olan var mı?

Öğrenci: Havadaki gaz taneciklerine çarparak gelir.

Öğretmen: Evet. Gaz taneciklerini titreterek bize ulaşır diyebiliriz. Özetleme.

Öğrenci: Evet 
Öğretmen: Peki, ses sadece hava gibi gazlardan oluşan ortamlarda mı yayılır?

Öğrenci: Evet.

Öğretmen: Örnek olayda pencereyi kapattık ses yine bize geldi. Ses bize gelirken hep hava ortamında mı geldi? Bilmediğini hissettirme

Öğrenci: Hayır, camdan da geçti.

Öğretmen: Cam maddenin hangi halidir.

Öğrenci: Katı.

Öğretmen: Bu durumda tekrar sorayım. Ses sadece hava gibi gazlardan oluşan ortamlarda $\mathrm{m}$ yayılır?

Öğrenci: Hayır, katılarda da yayılır.

Öğretmen: Peki, örnek olayda ses sırasıyla hangi ortamlardan geçti?

Öğrenci: Önce hava, sonra cam yani katı, sonra yine hava.

Öğretmen: Peki, bir leğene su koyup içinde iki taşı birbirine vurduğunuzda taşın sesini duyar mısınız?

Öğrenci: Evet.

Öğretmen: $\mathrm{Bu}$ durumda ses hangi ortamlardan geçti.

Öğrenci: Önce sıvı (su), sonra gaz (hava)

Öğretmen: $\mathrm{Bu}$ durumda ses maddenin hangi hallerinde yayılır?

Öğrenci: Katı, sıvı ve gaz. Özetleme.

Öğretmen: Aferin. Peki, maddenin hangi özelliğinden dolayı ses iletiliyordu?

Öğrenci: Titreşim hareketinden dolayı...

Öğretmen: Evet, bu sesin iletilmesidir. Peki, ses hava gibi gaz ortamda iletilebiliyorsa her ortamda da iletilir mi?

Öğrenci: Evet.

Öğretmen: Peki, ses uzayda iletilir mi?

Öğrenci: Hımm... Bilmediğini hissettirme

Öğretmen: Uzay neydi? Öğrenmiştik.

Öğrenci: Boşluk.

Öğretmen: Yani uzayda hava var mı?

Öğrenci: Hayır.

Öğretmen: Eğer hava yoksa bu ortamda taneciklerin titreşiminden bahsedebilir miyiz?

Öğrenci: Hayır.

Öğretmen: Titreşim yoksa sesten bahsedebilir miyiz?
Öğrenci: Hayır. Ses oluşması ve iletilmesi için titreşim gerekliydi.

Öğretmen: $\mathrm{Bu}$ durumda sesin iletilmesi için maddesel bir ortam gereklidir ve ses boşlukta yayılmaz diyebilir miyiz? Özetleme.

Öğrenci: Evet.

Öğretmen: Sesin titreşimle oluştuğunu katı, sıvı ve gazlarda iletildiğini gördük. Sesin boşlukta/uzayda iletilmediğini, iletilmesi için maddesel bir ortam gerektiğini gördük. Peki ses katı, sıvı ve gazların hangisinde daha iyi iletilir?

Öğrenci: En iyi gazlarda, sonra sıvılarda, en az katılarda iletilir.

Öğretmen: Peki, herkes dik otursun ve sırasına bir tık vursun. Daha sonra sıraya kulağını koyup sıranın diğer ucuna vursun. Hangisinde sesi daha iyi duydunuz? Basit deneylerle buldurmaya yönlendirme

Öğrenci: Kulağımızı sıraya koyduğumuzda.

Öğretmen: Bu durumda soruyu tekrar cevaplayın.

Öğrenci: Katılarda daha iyi iletilir.

Öğretmen: Peki, aynı ortamda farklı ses kaynaklarında aynı ses mi çıkar?

Öğrenci: Evet.

Öğretmen: Kaleminizle önce sıranıza vurun daha sonra sıranın demir ayaklarına vurun. Çıkan ses aynı mı? Basit deneylerle buldurmaya yönlendirme

Öğrenci: Hayır, sesler farklı.

Öğretmen: $\mathrm{Bu}$ durumda farklı ses kaynaklarında nasıl ses çıkar?

Öğrenci: Farklı ses kaynaklarında farklı sesler ç1kar. Özetleme.

Öğretmen: Aynı ses kaynağı farklı ortamlarda aynı mi duyulur?

Öğrenci: Evet.

Öğretmen: Cam bir su bardağın içine kaleminizle vurup sesi dinleyin. Daha sonra bardağa su doldurup aynı yere vurup sesi dinleyin. Çıkan sesler aynı mı? Basit deneylerle buldurmaya yönlendirme Öğrenci: Hayır, sesler farklı.

Öğretmen: Bu durumda nasıl bir sonuca vardınız?

Öğrenci: Aynı ses farklı ortamlarda farklı iletilir. Özetleme. 
Önerilen Süre: 2 ders saati

Konu/Kavramlar: Element, bileşik, atom, molekül, saf madde, karışım, tanecik

\section{Kazanımlar:}

F.7.4.1.3. Aynı veya farklı atomların bir araya gelerek molekül oluşturacağını ifade eder.

F.7.4.2.1. Saf maddeleri, element ve bileşik olarak sınıflandırarak örnekler verir.

Öğretmen: 6 sınıf maddelerin ortak özellikleri konusunda daha önce görmüştük. Hatırlayalım, maddelerin ortak özellikleri nelerdir? Bilinenlerle derse başlama

Öğrenci: Tanecikli yapı, boşluklu yapı ve titreşim hareketi.

Öğretmen: Tanecikli yapı derken ne ifade etmek istiyorsun? Yani tanecik nedir?

Öğrenci: Maddeleri oluşturan en küçük parçacıklardır.

Öğretmen: Bunlara örnek verebilir misiniz? Bu tanecikler neler olabilir?

Öğrenci: Atom olabilir. Altın (Au) atomlardan oluşmuştur.

Öğretmen: Evet. Sadece atom mu var? Peki, su $\left(\mathrm{H}_{2} \mathrm{O}\right)$ veya oksijen $\left(\mathrm{O}_{2}\right)$ nasıl oluşmuştur? Bilmediğini hissettirme

Öğrenci: Birden fazla atomdan oluşmuştur. Atom kümelerinden oluşmuştur.

Öğretmen: İki veya daha fazla atomun bir araya gelerek oluşturduğu atom kümelerine molekül denir diyebilir miyiz?

Öğrenci: Evet diyebiliriz.

Öğretmen: $O$ halde özetleyelim. Madde tanecikli yapılardan meydana gelir. Tanecikli yapı atom veya molekül olabilir. Atomlar Helyum (He), Neon (Ne), Demir $(\mathrm{Fe})$, Bakır $(\mathrm{Cu})$ veya Altın $(\mathrm{Au})$ gibi tek başına olur. Molekül 2 veya daha fazla atomun bir araya gelerek oluşturduğu atom kümeleridir. $\mathrm{Su}$ $\left(\mathrm{H}_{2} \mathrm{O}\right)$, karbondioksit $\left(\mathrm{CO}_{2}\right)$, oksijen $\left(\mathrm{O}_{2}\right)$, ozon $\left(\mathrm{O}_{3}\right)$ veya hidrojen $\left(\mathrm{H}_{2}\right)$ gibi. Özetleme

Tanecik Modelleri Oluşturma: Öğrencilerden oyun hamurlartyla oluşturabilecekleri çeşitli atom, molekül, element bileşik ve karışım modelleri yapmaları istenir. Daha sonra yapılandırılmış gridde yer alan modeller seçilerek tartışmaya devam edilir.

Yapılandırılmış Grid: Şimdi aşağıda verilen tanecik modellerini dikkatlice inceleyelim.

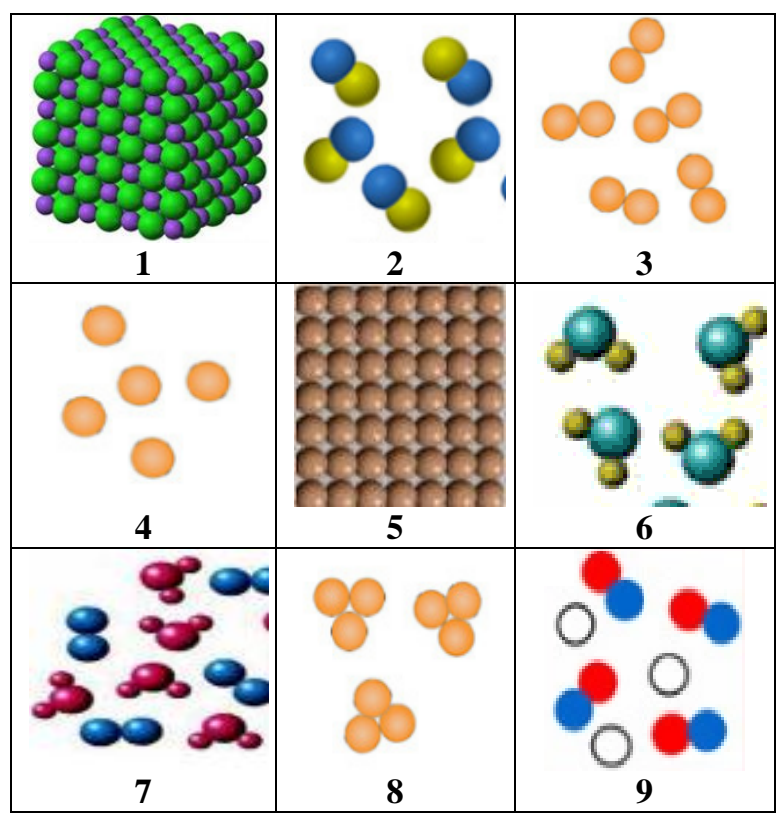

Öğretmen: Maddeler kaça ayrılır?

Öğrenci: Saf madde ve karışımlar olarak 2'ye ayrilır.

Öğretmen: Şöyle bir sınıflama yapabilir miyiz?

\begin{tabular}{|c|}
\hline \multicolumn{3}{|c|}{ Madde } \\
\cline { 2 - 2 } Saf Madde Karışım \\
\hline
\end{tabular}

Öğrenci: Evet yapabiliriz.

Öğretmen: Peki yukarıdaki kutucuklardan hangisi veya hangileri saf maddedir?

Öğrenci: 4 ve 5 . kutucuklar. 


\section{Öğretmen: Neden?}

Öğrenci: Tek atomlu oldukları için.

Öğretmen: Saf maddenin tanımı neydi hatırlıyor musunuz?

Öğrenci: Tek tür taneciklerden oluşan maddelerdir.

Öğretmen: Tek tür tanecik derken neyi kastediyorduk?

Öğrenci: Taneciklerin hepsinin birbirinin aynısı olmasını kastediyoruz.

Öğretmen: Peki tanecikler nelerdi?

Öğrenci: Atom ve moleküller. Bilmediğini hissettirme

Öğretmen: $O$ halde şimdi yeniden düşünelim kutucuklardan hangisi veya hangileri saf maddedir?

Öğrenci: $1,2,3,4,5,6$ ve 8 . kutucuklar.

Öğretmen: Neden?

Öğrenci: Bütün tanecikler (atom veya moleküller) birbirinin aynısıdır.

Öğretmen: Güzel! Peki hangileri karışımdır?

Öğrenci: 7 ve 9 farklı tür taneciklerden oluştuğu için.

Öğretmen: Peki! Şimdi, saf madde ile karışımın farkını söyleyebilir misiniz?

Öğrenci: Saf maddede tek tür tanecikler vardır. Karışımda birbirinden farklı tanecikler vardır. Özetleme.

Öğretmen: Saf maddeler kaça ayrılıyordu?

Öğrenci: Element ve bileşikler olarak ikiye ayriliyordu.

Öğretmen: Yukarıda yaptı̆̆ımız sınıflandırmayı genişletirsek nasıl bir sınıflandırma elde ederiz?

Öğrenci:

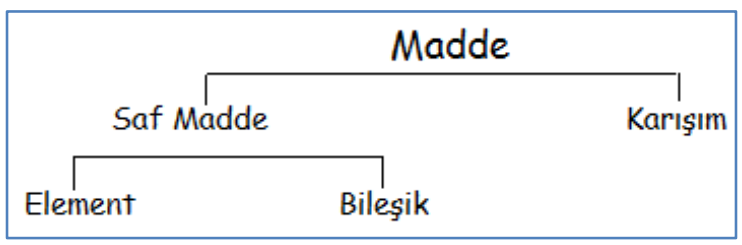

Öğretmen: Peki, yukarıdaki kutucuklardan hangisi veya hangileri elementi temsil etmektedir?

Öğrenci: 4. kutucuk.

Öğretmen: Neden?

Öğrenci: Tek atomdan oluşmuştur.

Öğretmen: Elementin tanımı neydi? Hatırlıyor muyuz?
Öğrenci: Tek tür atomlardan oluşan maddelere element denir.

Öğretmen: Peki tek tür olması için tek başına mı olması gerekiyor. Bilmediğini hissettirme

Öğrenci: Bilmiyorum...

Öğretmen: Şekil, büyüklük ve renk birbirinin aynis1 olan atomlardan 2 tanesi veya 3 tanesi bir araya gelirse farklı bir tür karışmış olur mu?

Öğrenci: Hayır, yine tek tür olur.

Öğretmen: $\mathrm{O}$ halde hangisi veya hangileri element sorusunu düşünüp yeniden cevaplar mısınız?

Öğrenci: $3,4,5$ ve 8 . kutucuklar.

Öğretmen: Neden?

Öğrenci: Çünkü hepsi aynı olan atomlardan oluşmuştur.

Öğretmen: Güzel! Peki, bu elementleri hangi tanecikler oluşturmuştur?

Öğrenci: 4 ve 5 . kutucuk atom. 3 ve 8 . kutucuk moleküldür.

Öğretmen: Bunlar yine de elementtir öyle değil mi?

Öğrenci: Evet, elementtir.

Öğretmen: $O$ halde elementleri nas1 siniflandırırsiniz?

Öğrenci: Atomdan oluşan elementler ve molekülden oluşan elementler diye ikiye ayırırız.

Öğretmen: Atomik yapılı element ve moleküler yapılı element diyelim. Özetleme

Bunları da sınıflandırmamıza ekleyelim

Öğrenci:

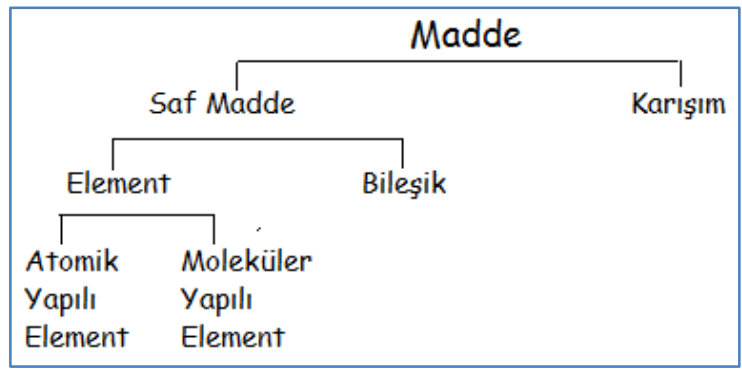

Öğretmen: 4. kutucuktaki model neyi temsil ediyor? Bu kutudaki madde ne olabilir?

Öğrenci: Helyum (He), Neon (Ne) olabilir.

Öğretmen: 5. kutucuktaki madde ne olabilir?

Öğrenci: Altın $(\mathrm{Au})$, Bakır $(\mathrm{Cu})$, Gümüş $(\mathrm{Ag})$ bütün metaller

Öğretmen: 3. kutucuktaki madde ne olabilir? 
Öğrenci: Hidrojen $\left(\mathrm{H}_{2}\right)$, oksijen $\left(\mathrm{O}_{2}\right)$

Öğretmen: 8. kutucuktaki madde ne olabilir?

Öğrenci: Ozon $\left(\mathrm{O}_{3}\right)$

Öğretmen: Güzel! Peki hangisi veya hangileri bileşiktir?

Öğrenci: 2, 6, 7 ve 9. kutucuklar.

Öğretmen: Peki bileşiğin tanımını hatırlayalım bileşik neydi?

Öğrenci: İki veya daha fazla farklı tür atomun bir araya gelerek oluşturduğu maddelere bileşik denir.

Öğretmen: Evet. Peki, 2 ve 6 numaralı kutucukta iki farklı tür bir araya gelmiş mi?

Öğrenci: Evet.

Öğretmen: Peki, 7 ve 9 da bir araya gelmiş mi?

Öğrenci: Gelmiş.

Öğretmen: Hepsi birbirinin aynısı mı?

Öğrenci: Hayır.

Öğretmen: $O$ halde bileşik diyebilir miyiz?

Öğrenci: Diyemeyiz.

Öğretmen: 1. kutudaki madde için ne dersiniz?

Öğrenci: İki farklı tür atom olduğu için bileşik diyebiliriz.

Öğrenci-2: Ama tanecik değil. Molekül değil.

Öğretmen: Evet farklı bir bakış açısı. Peki, bileşiğin tanımında tanecik ya da molekül var mı? Bilmediğini hissettirme

Öğrenci-2: Hımm. Yok öğretmenim.

Öğretmen: İki farklı tür atomdan oluştuğundan dolayı bileşik diyebiliriz. Buradan atomik yapılı ve moleküler yapılı element olduğu gibi bileşikleri de moleküler yapılı ve moleküler olmayan yapılı (kristal yapılı) olarak sınıflandırabiliriz. Özetleme

Bunları da sınıflandırmamıza ekleyelim

Öğrenci:

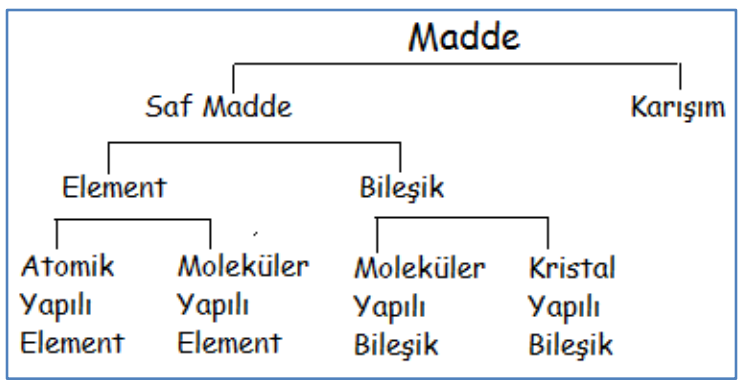

Öğretmen: 2. kutucuktaki madde ne olabilir?

Öğrenci: Karbon monoksit (CO)
Öğretmen: 6. kutucuktaki madde ne olabilir?

Öğrenci: su $\left(\mathrm{H}_{2} \mathrm{O}\right)$, karbon dioksit $\left(\mathrm{CO}_{2}\right)$

Öğretmen: Peki hangileri moleküldür?

Öğrenci: 1 ve 5. kutucuk moleküldür.

Öğretmen: Neden?

Öğrenci: En az iki atom var, düzenli ve boşluksuz.

Öğretmen: Sonsuz tane atom birbirine bağlanırsa molekül olur mu? Demir sonsuz tane (çok sayıda) $\mathrm{Fe}$ atomunun birleşmesinden oluşuyor. Demir molekül müdür? Bilmediğini hissettirme

Molekülün tanımı neydi hatırlıyor musunuz?

Öğrenci: Birbirine bağlı atomların oluşturduğu atom kümelerine molekül denir.

Öğretmen: Çok güzel şimdi bu tanımı düşünerek kutucuklardan hangisi ya da hangilerinin molekül olduğunu söyleyebilir misiniz?

Öğrenci: 2, 3, 6 ve 8. kutucuklar.

Öğretmen: Güzel! Peki, bunların hepsi bileşik mi, ya da element mi?

Öğrenci: Hayır. 3 ve 8 . kutucuk element, 2 ve 6. kutucuk bileşiktir. Yani elementte var bileşikte.

Öğretmen: Buradan molekül yapılı elementte olur bileşikte olur diyebilir miyiz?

Öğrenci: Evet diyebiliriz.

Öğretmen: Peki bileşik ve molekül arasındaki farkı söyleyebilir misiniz?

Öğrenci: Bileşikte en az iki farklı tür atom olması gerekiyor. Molekülde en az iki atom olması gerekiyor farklı olmasına gerek yok. İkisi de atom kümeleri şeklinde olmalıdır. Özetleme

* Öğrenciler atom molekül element bileşik kavramlarıly ilk kez 7. sınıfta karşılaştıklarından dolayı bu etkinlik kavramların tanımı yapıldıktan sonra kavramların birbirinden ayırt edilmesinin ögretilmesi amacıyla kullanılmalıdır. 
Önerilen Süre: 2 ders saati

Konu/Kavramlar: Asitler ve bazlar

Kazanımlar

8.3.4.1. Asit ve bazların genel özelliklerini kavrayarak günlük yaşamdan örnekler verir.

8.3.4.3. Asit ve bazların çeşitli maddeler üzerindeki etkilerini gözlemler.

Dün çok komik birkaç video izledim. Birinde çocuklara limon yediriyorlar, çocukların yüzleri gözleri şekilden şekle giriyor farklı oluyor. Diğer videoda ise biber yiyen insanlar acı çekiyorlar, yerlerinden zıplayıp ne yapacaklarını bilmiyorlar. Çok komik durumlar ortaya çıkıyordu.

Öğretmen: Limon yerken çocukların yüzleri neden değişiyor?

Öğrenci: Ekşi olduğu için...

Öğretmen: Sizde de öyle oluyor mu?

Öğrenci: Bazen...

Öğretmen: Diğer meyve ya da sebzelerde de öyle oluyor mu?

Öğrenci: Erikte oluyor. Bazen çilekte...

Öğretmen: Peki biber yiyen insanlar neden acı çekiyor.

Öğrenci: Acı olduğu için. Biberlerin bazıları çok ac1.

Öğretmen: Çevremizde acı olan başka neler var? Sadece yiyecek olarak düşünmeyin.

Öğrenci: Sabun ya da şampuan gözümüze kaçtığında acitıyor. Önceden daha çok oluyordu.

Öğretmen: Hiç sabun ya da şampuan ağzınıza geldi mi? Tadı nasıl biliyor musunuz?

Öğrenci: Ac1

Öğretmen: Şimdi göz acıtmayanlarda çıktı ancak doğal sabunlar gözle temas ettiğinde gözlerimizi acıtır. Peki, yediğimiz meyveler hangi özelliğinden dolayı ekşi veya acı oluyor oluyor? Bilmediğini fark ettirme

Öğrenci: Bilmiyorum...

Öğretmen: Aileniz sizin kola içmenize izin veriyor mu?

Öğrenci: Bazen. Çoğunlukla izin vermiyor.

Öğretmen: Neden izin vermiyor peki?
Öğrenci: Çünkü kola asitli olduğu için midemize zarar verdiğini söylüyor.

Öğretmen: Evet doğru söylüyorlar. Kolanın boğazımızı tahriş etmesinden de bunu anliyoruz. Ancak içinde bulunan fazlaca şeker miktarı kolayı bize tatlı hissettiriyor. Peki, asit nedir biliyor muyuz?

Öğrenci: Zararlı, yakıcı maddelerdir.

Öğretmen: Hepsi zararlı mıdır?

Öğrenci: Bilmiyorum. Bilmediğini fark ettirme

Öğretmen: Bu konuya tekrar geleceğiz. Çocuklar limon, erik gibi meyveler asidik, sabun şampuan gibi maddeler bazik maddelerdir. Şimdi bunların özelliklerini karşılaştırmalı olarak bulalım mı?

Öğrenci: Evet.

Öğretmen: Limon, yeşil erik, yeşil elmanın tadı nasıldır?

Öğrenci: Ekşi...

Öğretmen: Peki sabun şampuan, biberin tadı nasildır?

Öğrenci: Acı

Öğretmen: O zaman asitler ekşi, bazlar acıdır diyebilir miyiz? Özetleme.

Öğrenci: Evet.

Öğretmen: Asitler midemizi ne yapıyordu?

Öğrenci: Yakıyordu.

Öğretmen: Peki asitlerin yakıcı özelliğine karş1 bazlarda hangi özellik var?

Öğrenci: Hımm. Bilmiyorum...

Öğretmen: Temizlik malzemeleri kirleri ne yapar? Öğrenci: Söker.

Öğretmen: $O$ halde asitler yakıcı bazlar sökücü diyebilir miyiz?

Öğrenci: Evet.

Öğretmen: Sabun ya da şampuanı elinize alıp ovuşturduğunuzda elinizi nasıl hissedersiniz?

Öğrenci: Elimiz kayganlaşır. 
Öğretmen: Güzel! Peki, daha önce görmüştük limondan elektrik üretilir miydi?

Öğrenci: Evet üretilirdi. Limona küçük bir ampul bağladığımızda ampul yakmıştı.

Öğretmen: Limon asitti değil mi?

Öğrenci: Evet

Öğretmen: $\mathrm{Bu}$ durumda asitler elektriği iletir diyebilir miyiz?

Öğrenci: Evet elektriği iletir diyebiliriz.

Öğretmen: Asitler gibi bazlarında sulu çözeltisi elektriği iletir. Şimdi size birkaç asidin formülünü vereceğim. Bakalım formüllerde ortak olan bir şey görebilecek misiniz?

Hidroklorik asit $(\mathrm{HCl})$, sülfürik asit $\left(\mathrm{H}_{2} \mathrm{SO}_{4}\right)$, nitrik asit $\left(\mathrm{HNO}_{3}\right)$

Öğrenci: Hepsinde $\mathrm{H}^{+}$var.

Öğretmen: Evet doğru bildiniz. Şimdi de size birkaç bazın formülünü vereceğim. Bakalım formüllerde ortak olan bir şey görebilecek misiniz?

Potasyum hidroksit (KOH), sodyum hidroksit $(\mathrm{NaOH})$, kalsiyum hidroksit $\left(\mathrm{Ca}(\mathrm{OH})_{2}\right)$

Öğrenci: Bunlarda da $\mathrm{OH}^{-}$var.

Öğretmen: Evet, bu durumda suyun içinde iyonlarına ayrılırlar ve asitler $\mathrm{H}^{+}$(hidrojen) bazlar $\mathrm{OH}^{-}$(hidroksil) iyonu verir diyebilir miyiz? Özetleme.

Öğrenci: Evet, diyebiliriz.

Öğretmen: Bunun istisnai durumları yok mudur?

Öğrenci: Hımm. Bilmiyorum...

Öğretmen: Asetik asit $\left(\mathrm{CH}_{3} \mathrm{COOH}\right)$ formülünde $\mathrm{OH}$ olduğu halde sulu çözeltisinde $\mathrm{CH}_{3} \mathrm{COO}^{-}$ve $\mathrm{H}^{+}$ olarak iyonlarına ayrıldığından dolayı $\mathrm{CH}_{3} \mathrm{COOH}$ (asetik asit) asittir. Amonyak $\left(\mathrm{NH}_{3}\right)$ formülünde $\mathrm{OH}^{-}$olduğu halde sulu çözeltisinde $\mathrm{NH}_{4}{ }^{+}$ve $\mathrm{OH}^{-}$ olarak iyonlarına ayrıldığından dolayı $\mathrm{NH}_{3}$ (amonyak) bazdır. Özel durumları açıklama

Öğrenci: Yani bazların formülünde çoğunlukla $\mathrm{OH}^{-}$var ama hepsinde olması şart değil, sulu çözeltisinde $\mathrm{OH}^{-}$verebilir. Aynı şey asitler içinde geçerlidir.

Öğretmen: Evet. Peki, limon, yeşil erik, yeşil elma asidik dedik. Hepsinin asitlik derecesi aynı mıdır? Hepsinin ekşiliği aynı mı?

Öğrenci: Hayır, bazıları çok ekşi bazıları daha az ekşi.

Öğretmen: $O$ zaman asitlik dereceleri farklıdır diyebilir miyiz?
Öğrenci: Evet.

Öğretmen: Tartışmanın başında asitler zararlı ve yakıcıdır demiştiniz hatırladınız mı?

Öğrenci: Evet

Öğretmen: Şimdi ne dersiniz?

Öğrenci: Limon yediğimize göre hepsi zararlı ve yakıcı değildir.

Öğretmen: Peki asitler nelere zarar verir?

Öğrenci: Elimizi yakar, bir şeye döküldüğünde onu yakar.

Öğretmen: Bunlar kuvvetli asitler için geçerlidir. Mutfakta limon kesilirken mermere temas etmemesine dikkat edilir. Bunun nedeni nedir?

Öğrenci: Mermeri yakıyor mu?

Öğretmen: Evet. Ama bir anda olmuyor tabi sürekli limon temas ettiğinde zamanla mermer yıpranıyor. Peki, asitler ne tür kaplarda saklanır?

Öğrenci: Plastik kaplarda saklanır.

Öğretmen: Neden metal kaplarda saklanmaz?

Öğrenci: Mermeri yıpratıyordu. Metali de yıpratiyordur.

Öğretmen: Evet. Metallerle tepkimeye gireceklerinden dolayı plastik kaplarda saklanırlar. Buradan asitlerin metallere etki ettiğini söyleyebilir miyiz?

Öğrenci: Evet.

Öğretmen: Peki, bazların etki ettiği maddeler var $\mathrm{m} 1$ ?

Öğrenci: Hımm. Vardır.

Öğretmen: Temizlik malzemeleri çoğunlukla bazdır. Bunu dikkate alabilirsiniz.

Öğrenci: Camlar sürekli temizlenince çizilir. Bulaşık makinesiyle yıkanan bardaklar belli bir süre sonra çizildiğini renginin bulanıklaştığını görürüz.

Öğretmen: Aynı şeyi tabaklar için söyleyebilir miyiz?

Öğrenci: Evet. Tabaklarda yıpranır.

Öğretmen: Tabaklar neden yapılmıştır?

Öğrenci: Porselenden yapılmıştır.

Öğretmen: $\mathrm{Bu}$ durumda bazlar cam ve porselene etki eder diyebilir miyiz?

Öğrenci: Evet, diyebiliriz.

Öğretmen: Şimdi asit ve bazların öğrendiğimiz özelliklerini özetleyelim. Nelerdi bunlar? Özetleme.

Öğrenci: 


\begin{tabular}{|c|c|}
\hline Asitler & Bazlar \\
\hline$\checkmark \quad$ Tatları ekşidir & $\checkmark \quad$ Tatları acıdır \\
\hline $\begin{array}{ll}\checkmark & \text { Sulu çözeltileri } \mathrm{H}^{+} \\
& \text {iyonu verir. }\end{array}$ & $\begin{array}{l}\checkmark \text { Sulu çözeltileri } \mathrm{OH} \\
\text { iyonu verir. }\end{array}$ \\
\hline $\begin{array}{l}\checkmark \text { Sulu çözeltileri } \\
\text { elektriği iletir. }\end{array}$ & $\begin{array}{ll}\checkmark & \text { Sulu çözeltileri } \\
& \text { elektriği iletir. }\end{array}$ \\
\hline$\checkmark$ Yakıcıdır & $\begin{array}{ll}\checkmark \text { Sökücüdür } \\
\end{array}$ \\
\hline $\begin{array}{l}\checkmark \quad \text { Metal ve mermere } \\
\text { etki eder }\end{array}$ & $\begin{array}{l}\checkmark \quad \text { Cam ve porselene } \\
\text { etki eder }\end{array}$ \\
\hline $\begin{array}{ll}\checkmark & \text { Ele yanma hissi } \\
& \text { verir }\end{array}$ & $\begin{array}{ll}\checkmark & \text { Ele kayganlık hissi } \\
& \text { verir }\end{array}$ \\
\hline
\end{tabular}

Öğretmen: Meyve ve sebzelerden asit olanlara örnekler hangileriydi?

Öğrenci: Limon, portakal, çilek, üzüm...
Öğretmen: Yoğurt, süt gibi besinleri de asit grubunda sayabiliriz. Peki baz olan besin var miydı?

Öğrenci: Biber, ıspanak, salata...

Öğretmen: Buradan besinlerin hepsi asidiktir diyebilir miyiz?

Öğrenci: Hayır.

Öğretmen: Evet besinler asidiktir ya da baziktir genellemesi yapamayı. Peki, temizlik malzemelerinin hepsi bazik midir?

Öğrenci: Hımm. Bilmiyorum...

Öğretmen: tuz ruhu seyreltik hidroklorik asittir $(\mathrm{HCl})$ buradan tüm temizlik malzemeleri baziktir genellemesi yapamayı. 